\title{
Etnología y etnias de la Turdetania en época prerromana
}

\author{
Francisco José García Fernández \\ Universidad de Sevilla ${ }^{1}$
}

\section{Resumen}

Frente a la imagen tradicional generada por la arqueología historicista, la configuración étnica de la Turdetania constituye una realidad sumamente compleja, dinámica e inestable, sujeta a constantes variaciones como consecuencia de diferentes circunstancias políticas, sociales y culturales. Recientes planteamientos teórico-metodológicos procedentes de la Sociología y la Antropología permiten al arqueólogo abordar este problema desde nuevas perspectivas que cuestionan el valor intrínseco las fuentes literarias y la documentación arqueológica en la definición de grupo étnico. Ambas deben ser tenidas en cuenta únicamente en la medida en que participen activamente en la construcción de la identidad étnica. No hay que olvidar, sin embargo, la dificultad que entraña definir grupos étnicos en el espacio y en el tiempo, habida cuenta de que más que un fenómeno, la etnicidad constituye un proceso continuo. En esta ocasión nos centraremos en los dos principales grupos culturales de la Turdetania: los turdetanos y los púnicos que, lejos de constituir unidades étnico-territoriales homogéneas, presentan una amplia variedad de situaciones singulares.

Palabras clave: Península Ibérica, Turdetania, Edad del Hierro, etnicidad, testimonios literarios, cultura material.

\begin{abstract}
Despite the traditional image generated by historicist archaeology, the ethnic composition of Turdetania is a complex, dynamic and unstable reality in a continual process of changing as a result of different political, social and cultural circumstances. Newest theoretical and methodological hipothesis from Sociology and Anthropology let the archaeologist focus on this problem from new points of view questioning the inherent value of literarial texts and archaeological resources to define ethnic group. Both must be considered as contributors on the construction of the ethnic identity. We must not forget the difficulty to define ethnic groups in space and time because ethnicity is a constant process not a phenomenon. In this work, we will focus on the two principal groups in Turdetania: turdetanians and punics, who present a wide variety of particular situations, instead of homogeneous ethnic and territorial units.
\end{abstract}

Keyword: Neolithic, Península Ibérica, Turdetania, Iron Age, ethnicity, literary sources, material culture.

La Historia y, dentro de ella, la Arqueología, como el resto de las disciplinas científicas, se encuentra sometida a modas y vaivenes, etapas caracterizadas por determinados planteamientos teóricos o metodológicos y por un interés diverso en determinados periodos históricos o aspectos especí-

1 Trabajo realizado en el marco del Proyecto "Antecedentes y desarrollo económico de la romanización en Andalucía Occidental” (BHA2002-03447), den- ficos de la investigación. A ello no es ajena la dinámica interna de nuestras sociedades, que impone una forma de ver, interpretar y explicar el pasado, la mayoría de las veces dependiente de los paradigmas ideológicos y epistemológicos imperantes o, lo que es peor, subordinada a coyunturas políticas concre-

tro del Grupo de Investigación "De la Turdetania a la Bética", del Departamento de Prehistoria y Arqueología de la Universidad de Sevilla. 
tas. De este modo el científico, más o menos condicionado por su propio contexto social y cultural, trata de satisfacer no sólo las incógnitas surgidas a lo largo del proceso de investigación, objetivamente individualizadas, sino también la demanda de la comunidad científica y, más aún, del resto de la sociedad receptora de la información.

Sin esta reflexión, común por otra parte a todos los que nos dedicamos al campo de las "humanidades", sería difícil entender el auge alcanzado en los últimos años por los estudios de paleoetnología, etnicidad y etnogénesis en las arqueologías prehistóricas e históricas $\mathrm{y}$, por supuesto, en la Antropología y la(s) historia(s). Ya se deba al triunfo del pensamiento postmoderno, que trae consigo una nueva visión del "otro" (González Ruibal, 2003), o simplemente a la paulatina asimilación por parte de la New Archaeology de los presupuestos básicos de la Antropología - no es éste el momento de discutir sobre cuál fue la madre del cordero-, lo cierto es que desde finales de los años ochenta y sobre todo durante la década de los noventa, la Etnología ocupa un lugar destacado en los estudios sobre prehistoria y protohistoria de la Península Ibérica. Con varios años de retraso respecto al resto de las escuelas europeas, las cátedras de Prehistoria, Arqueología e Historia Antigua de algunas universidades españolas empezaron a interesarse por el origen y evolución de las identidades "indígenas" de la Hispania prerromana, así como por los procesos de transformación que sucedieron a la conquista romana en el seno de estas sociedades. En ello jugó un papel destacado el desarrollo del "Estado de las Autonomías" y el surgimiento de políticas culturales de sesgo regionalista o nacionalista desde los nuevos gobiernos autonómicos (Díaz-Andreu, 1995; Ruiz Zapatero, 1996: 189-190), aunque bien es cierto que se corre el riesgo, como ya ha ocurrido en alguna ocasión, de forzar los argumentos hasta límites insospechados con el fin de legitimar determinadas aspiraciones políticas (Ferrer y García, 2002: $133)^{2}$, hasta el extremo de hacer coincidir unidades administrativas actuales con los territorios de los grupos étnicos protohistóricos (González Morales,

2 "Los nacionalismos y regionalismos conscientemente potencian estos estudios como un medio directo o indirecto de justificar y sus aspiraciones futuras buscando sus raíces más remotas en la Antigüedad o en el Medievo, recuperando una edad dorada que "histórica" y sentimentalmente los vincule y cohesione internamente $y$, de manera simultánea, los segregue de los otros”. La historia, una vez más, se convierte en un instrumento de manipulación ideológica, eso sí, enmascarado bajo la aureola de progresismo y "buenrrollismo" cultural -per-
1992).

Polémicas aparte, la aparición en 1992 del volumen Paleoetnología de la Península Ibérica, que reúne tanto reflexiones generales como estudios regionales sobre las comunidades prerromanas del conjunto de Iberia, supone un punto de inflexión o, mejor dicho, un punto de confluencia de diferentes líneas de investigación que habían tenido su inicio en la década anterior en áreas tan dispares como el cuadrante noroccidental (por ejemplo, Solana, 1991) o Andalucía (Ruiz Mata, 1987; Escacena, 1989; Iniesta, 1989, entre otros). A partir de este momento los ensayos sobre paleoetnología se multiplican, aunque con un resultado diverso, centrando su atención en las áreas de mayor complejidad, principalmente aquellas que se encuentran dentro de lo que lingüísticamente se conoce como la Iberia "indoeuropea" (Gorrochategui, 1993: 411). Se estaban empezando a superar algunas barreras seculares que todavía seguía arrastrando la historiografía española, tales como la cuestión celtibérica (Ciprés, 1993; Gómez Fraile, 1997), la "iberización" de la Baja Andalucía (Escacena, 1989 y 1992) -sobre la que luego incidiremos- o la propia carga semántica de los términos "Iberia", "Iberos" y "celtas" (Domínguez Monedero, 1983; Gómez Fraile, 1999; Cruz Andreotti, 2002; Kurtz, 1995; Díaz Santana, 2003, entre otros). No obstante, la Arqueología Filológica y el Historicismo Cultural continúan aún ejerciendo una poderosa influencia, más a nivel metodológico que teórico, en las reconstrucciones paleoetnológicas llevadas a cabo en los últimos años. La obsesión por hacer coincidir etnias con "culturas arqueológicas", incluso cuando los nombres de aquellas provienen de fuentes escritas ajenas o desconocedoras (en su mayoría) de la realidad indígena peninsular, ha dado lugar a no pocos errores y contradicciones. A ello hay que añadir la dificultad que supone la interpretación del registro material y la definición de "culturas arqueológicas"3 a partir de un conjunto de ítems que se presumen representativos de una determinada comunidad (Downs, 1998: 42-43; Ferrer y García, 2002: 145146; Ferrer y Prados, 2001-02: 274). Sobre el uso de mítase la licencia- que caracteriza a algunas administraciones locales.

3 Venimos aceptando de forma operativa la definición de M. Ruiz Gálvez (1987: 251), para quién "cultura arqueológica" hace referencia a "un territorio físico concreto donde, en un periodo cronológico determinado, se producen unas mismas manifestaciones, reflejadas en un patrón de asentamiento, un tipo de enterramiento y unos artefactos que, con independencia de las posibles variantes locales, son comunes a lo largo de éste". 
estos ítems como indicadores étnicos volveremos más adelante. Por último, queda mencionar la ausencia generalizada de una percepción diacrónica de la distribución étnica, que describa tanto los cambios que se suceden a nivel social y cultural $-\mathrm{y}$ que afectan inevitablemente a la propia identidad-, como su repercusión a escala territorial.

Por lo que respecta a los "pueblos" de la Turdetania ${ }^{4}$, las interpretaciones más recientes tampoco han aportado soluciones satisfactorias. Ello se debe, como decimos, a la costumbre generalizada de pretender conciliar en un mismo mapa todos los étnicos transmitidos por la tradición grecolatina en casi mil años de producción literaria; así como a los frecuentes intentos de establecer una correspondencia entre los datos aportados por la Arqueología y las informaciones procedentes de las fuentes escritas. El caso de R. Lacalle (1997), por citar algún ejemplo, puede resultar llamativo, ya que practica un ensayo de reconstrucción paleoetnológica en el que se entremezclan testimonios literarios de diversa índole y cronología con los datos arqueológicos, tomando como base la distribución espacial de las representaciones en piedra de leones. El resultado es un mosaico étnico sincrónico y contradictorio donde encontramos conviviendo al mismo tiempo turdetanos, túrdulos, mastienos y libiofenicios o bástulofenicios $(i)$, a la vez que se modifican las "fronteras culturales" para forzar la relación entre las diferentes fuentes de información. A. Iniesta (1989), por su parte, aunque reconoce a los mastienos y los bastetanos como una misma realidad étnica en dos momentos distintos, obvia sin embargo el hecho de que el territorio de los primeros corresponda con el hinterland de los asentamientos fenicios de época arcaica y los identifica con las poblaciones autóctonas del Bronce Final que ocupaban la costa suroriental de la Península Ibérica. Del mismo modo, T. Chapa y J. Pereira (1994) identifican a los mastienos con los bastetanos del interior y no con los bástulos, que habitan precisamente el mismo territorio.

4 Ante la ausencia de un marco geográfico más adecuado y preciso vamos a utilizar el que transmiten las fuentes literarias de época tardohelenística, principalmente Estrabón, que reflejan el proceso a través del cual la realidad geo-etnográfica de la antigua región tartésica es percibida, aprehendida y descrita por los geógrafos e historiadores de la "romanización". De este modo, y a pesar de su falta de nitidez, entendemos por "Turdetania" la región bañada por el río Guadalquivir y sus afluentes, que limita hacia el norte con las primeras estribaciones de Sierra Morena, hacia el este con las sierras Sudbéticas y hacia el oeste y noroeste con el curso del río Guadiana,
Otros investigadores, como L. Silgo Gauche (1992), han intentado establecer unos límites más o menos nítidos entre los grandes conjuntos étnicos de la Turdetania a partir de las fuentes clásicas, la lengua, la toponimia y antroponimia de época romana. En sentido opuesto D. Ruiz Mata (1997 y 1998) piensa que los tartesios, una vez asimilado el impacto cultural durante el periodo Orientalizante, formaron junto con los fenicios una cultura homogénea, que no es otra que la turdetana. En último lugar, el mapa propuesto por A. Ruiz y M. Molinos (1993), si bien procura respetar la diacronía de las fuentes, sitúa en un mismo territorio a elbestios, elbisinos y cilbicenos -a la sazón distintas denominaciones de un mismo grupo étnico casi desconocido-, junto a los tartesios, libiofenicios y mastienos, en el mismo orden en el que son citados en la polémica Ora Maritima de Avieno ${ }^{5}$; aunque más adelante vuelve a incluir a los turdetanos entre el aglomerado de pueblos que conocemos con el desafortunado término de "cultura ibérica".

Afortunadamente en los últimos años están dando sus frutos nuevas líneas de investigación que afrontan el estudio de las etnias y la etnicidad en la Hispania prerromana desde planteamientos teóricos metodológicos más coherentes con la realidad etnológica y alejados de los paradigmas clásicos de la Arqueología Filológica y de la correspondencia etnia-cultura material que defiende la arqueología historicista. Paralelamente al auge de nuevas disciplinas como la Etnoarqueología o la Etnohistoria, se impone una práctica historiográfica más completa que integra las aportaciones de la Arqueología con las de la Antropología, la Epigrafía, el análisis textual, la Lingüística, etc. como resultado, a menudo, de experiencias interdisciplinares. Destaca, por ejemplo, la monografía de F. Burillo sobre los celtíberos (1998), el artículo de G. Ruiz Zapatero y J.R. Álvarez-Sanchís sobre la identidad de los vetones (2002), una aproximación novedosa y profunda a la etnicidad de los pueblos paleohispánicos que recoge

así como la costa que se extiende entre la desembocadura del río Guadiana y el Estrecho de Gibraltar, aunque en determinados momentos también puedan integrarse en Turdetania las poblaciones que se sitúan a lo largo del litoral de Andalucía Oriental (García Fernández, 2002).

5 Sobre el carácter exclusivamente literario del poema de Avieno, dentro del contexto cronológico y cultural en el que se encuentra inserto el autor, y las dificultades que entraña su uso como fuente de datos geográficos, destacamos González Ponce (1995), que recoge básicamente toda la bibliografía anterior. 
las últimas propuestas de la antropología y arqueología anglosajonas o, más recientemente, la reflexión de B. Díaz Santana sobre la "identidad" celta (2003).

Por lo que respecta a la Hispania meridional, los trabajos de J.L. Escacena sobre los turdetanos (1989 y 1992) constituyen el primer intento serio de establecer los elementos más apropiados para definir los parámetros sobre los que se asienta su identidad. Posteriormente M. Downs (1998), que parte de los mismos presupuestos de Escacena sobre la ausencia de una equivalencia entre identidad y cultura material, hace hincapié en la heterogeneidad de la "cultura turdetana" y en los problemas inherentes a la construcción de la identidad a partir de la documentación literaria y arqueológica ${ }^{6}$. Una reciente síntesis sobre las posibilidades que ofrecen los testimonios literarios y arqueológicos para la reconstrucción del conglomerado étnico que compone la Turdetania lo tenemos en Ferrer y García (2002). Por su parte, E. Ferrer Albelda ha definido un "espacio cultural púnico", que "abarcaría básicamente la costa mediterránea y atlántica desde Almería hasta Huelva y algunos territorios del interior como la campiña (Asido o Carmo), así como determinadas localidades ribereñas del Lago Ligustino" (1998: 39-40), dentro del cual se encuentra el área ocupada por los Bástulos o Bástulo-Púnicos, que es como la tradición literaria grecolatina denomina a los púnicos de Iberia (Ferrer y Prados, 2002; Ferrer, 2004).

Aunque todavía queda mucho por hacer, nos encontramos en un momento privilegiado en el que la investigación está empezando a afrontar seriamente una problemática histórica y arqueológica que se muestra mucho más compleja y diversa de lo que en principio podía aparentar. Los objetivos de este ensayo van encaminados en ese sentido. Pretendemos aproximarnos a la diversidad étnica de la Turdetania a partir del análisis crítico de las fuentes literarias y arqueológicas, así como también del estudio de la etnicidad desde el punto de vista de la Antropología, incidiendo en la génesis y la naturaleza -endógena o exógena- de los elementos sobre los que se asientan las señas de identidad de sus habitantes. Esta aproximación deberá tener en cuenta, evidentemente, el carácter diacrónico del proceso y la constante revisión a la que se ve sometida la conciencia y los valores colectivos. Partimos de la idea

6 En esta misma línea nuestro trabajo "Turdetania, turdetanos y cultura turdetana" (García Fernández, 2002) incide sobre la necesidad de interpretar los términos "Turdetania" y "turdetanos" dentro de la tradición literaria e historiográfica que los genera -es decir, dentro del de que las fronteras entre los diferentes grupos no son nítidas, sino que se difuminan hasta a veces desaparecer gracias al contacto interétnico. Trataremos de sostener, en definitiva, la existencia de áreas culturales mixtas en las que la convivencia en un mismo espacio de diferentes "grupos étnicos" con diferentes niveles de organización socio-política puede dar lugar a fenómenos de identidad múltiple o la convergencia de distintos niveles de identidad.

\section{LA ETNOLOGÍA Y EL PRINCIPIO DE INCER- TIDUMBRE, ¿SE PUEDE REALMENTE CONO- CER A UNA ETNIA?}

En 1926 Werner Heisenberg, siguiendo la hipótesis cuántica de Max Planck (padre de la física cuántica), formuló su famoso principio de incertidumbre, según el cual es imposible conocer la posición exacta de una partícula sin modificar aun levemente su velocidad, o lo que es lo mismo: cuanto mayor sea la precisión con que se trate de medir la posición de una partícula, menor será la exactitud con que se podrá medir su velocidad, y cuanto mayor sea la precisión con la que se mida la velocidad de una partícula, tanto mayor será la incertidumbre de su posición (Hawking, 1993: 83). En esta teoría "las partículas ya no poseen posiciones y velocidades definidas por separado, pues éstas no podrían ser observadas. En vez de ello, las partículas tienen un estado cuántico, que es una combinación de posición y velocidad" (Hawking, 1993: 84). La mecánica cuántica introduce, pues, un elemento inevitable de incapacidad de predicción, una aleatoriedad universal que afecta a los propios fundamentos de la ciencia y la filosofía modernas. Aunque las implicaciones del principio de incertidumbre no han sido aún suficientemente valoradas para otros campos del saber, supuso el final del paradigma de las "ciencias exactas" y enterró definitivamente el modelo de universo determinista y predecible que había caracterizado a la física clásica (Bohr, 1988).

Evidentemente no quiero decir con esto que los modelos de la física sean capaces de describir el comportamiento humano, individualmente y mucho menos a nivel colectivo. Simplemente trato de demostrar que los fundamentos sobre los que se asientan actualmente las ciencias denominadas "puras" parten de los mismos principios de indeter-

contexto de la conquista romana- y, en consecuencia, asumir la incongruencia histórica que implica el uso del término "cultura turdetana" para definir la herencia poblacional y cultural de Tartesos durante los siglos $\mathrm{V}$ al III a.C. 
minación que han actuado tradicionalmente sobre las ciencias "humanas". Ello nos coloca en una situación ventajosa con respecto a aquellas, por cuanto hace años que aceptamos voluntaria y humildemente el carácter relativo y limitado de nuestras aproximaciones, a la historia del hombre, la cultura y la sociedad. Por lo tanto, no debe suponer un gran esfuerzo admitir que es, por "principio", imposible conocer los parámetros exactos que definen a una sociedad, más aún si se trata de una sociedad desaparecida de la que únicamente conservamos una parte de sus vestigios materiales y, como mucho, algunos documentos escritos. $\mathrm{Si}$ a este problema añadimos el factor tiempo, es decir, la propia evolución interna de un determinado colectivo durante su etapa de existencia, así como las transformaciones que pueden hacerlo devenir en una realidad totalmente distinta, nos encontramos ante el mismo problema al que se enfrenta el pensamiento postmoderno al tratar de describir observaciones de una realidad que se muestra, por "principio", intangible.

No pienso agotar el espacio disponible divagando sobre los fundamentos epistemológicos de las ciencias "humanas", no es ese el objetivo de esta reflexión. Mi interés se centra en la problemática que encierra el estudio de las etnias y más concretamente de las etnias "históricas" que han dejado testimonios materiales de su existencia. Antes bien, cabría preguntarse qué entendemos por etnicidad. El mencionado artículo de G. Ruiz Zapatero y J.R. Álvarez Sanchís (2002) recoge las últimas aportaciones conceptuales sobre "identidad étnica" y "grupos étnicos" llevadas a cabo desde la Arqueología por S. Shennan (1989), S. Jones (1997), S. James (1999) y J. Hall (1997 y 1998). Del mismo modo, en un reciente trabajo B. Díaz Santana (2003) ha realizado un recorrido por los diferentes paradigmas epistemológicos desde los cuales se ha abordado el problema de la etnicidad. Para evitar reiteraciones innecesarias me ceñiré a las ideas básicas, que tienen su origen en la antropología anglosajona de finales de los años sesenta del pasado siglo.

Según Barth (1974: 10), "los grupos étnicos son categorías de adscripción e identificación que son utilizadas por los actores mismos y tienen, por tanto, la característica de organizar interacción entre los individuos", de tal modo que, "aunque las categorías étnicas presuponen diferencias culturales, es preciso reconocer que no podemos suponer una misma relación de paridad entre las unidades étnicas y las similitudes o diferencias culturales. Los rasgos que son tomados en cuenta no son la suma de diferencias "objetivas", sino solamente aquellas que los actores mismos consideran significativas". Así pues, "ni los caracteres raciales, ni la herencia biológica, ni la lengua, ni los aspectos formales de la cultura constituyen por sí solos, ni necesariamente, elementos caracterizadores de los grupos étnicos, sino que estos se definen en función de la autoadscripción que los individuos hacen de ellos mismos a un grupo y de la adscripción realizada por los demás" (Zamora, 1988: 399). Se trata, en cualquier caso, de una visión estática y subjetiva de la etnicidad, "que desemboca en cierto determinismo cultural, ya que el individuo está constreñido por su identidad étnica” (Díaz Santana, 2003: 301).

Frente a esta perspectiva todavia bastante esencialista o primordialista la antropología funcionalista, y en consecuencia también la New Archaeology, ha hecho hincapié en el carácter instrumental ("funcional") de la identidad. Desde este punto de vista, la etnicidad no es más que un instrumento de la organización sociopolítica que le permite mantener la cohesión del grupo social y competir con otros grupos por el control del territorio y el acceso a los recursos económicos. Es decir, "las identidades étnicas se desarrollan en respuesta a requerimientos funcionales y organizativos, y pueden no ser conscientemente asumidas como tal por los seres humanos. Son las condiciones contemporáneas de los individuos las que hacen que emerjan las identidades o se activen". Nos encontramos ante una visión "objetivista" de la etnicidad, "ya que rechaza la adscripción categórica subjetiva y consciente de los individuos como el criterio esencial de la identidad étnica" (Díaz Santana, 2003: 302).

Como resultado de estas dos posturas, la etnicidad es entendida hoy por antropólogos y arqueólogos como una construcción subjetiva, que puede estar basada en parte (1) en elementos heredados -como la lengua, la religión, el origen o el territorio (Ruiz y Álvarez-Sanchís, 2002: 256)- pero que, por encima de todo, (2) es el resultado de la autoconceptualización y el autoreconocimiento de un grupo por oposición a otros, a partir de una diferenciación cultural percibida y/o descendencia común (Jones, 1997: xiii). En consecuencia, "la diferencia es esencial para que se active empíricamente una etnicidad latente, y esta diferencia es mucho más percibida por aquellos grupos humanos que están en mayor contacto con otros grupos de su entorno" (Díaz Santana, 2003: 322, siguiendo a Eriksen, 1993). Desde una perspectiva constructivista la etnicidad se concibe, por tanto, "como una herramienta de clasificación, que crea orden en un universo social desordenado, dando al individuo modos de comportamiento intra e intergrupal que modelan la práctica social constantemente" a través de la apropiación de símbolos socialmente significativos (ibidem: 304). 
Teniendo en cuenta su carácter discursivo y autoconsciente la etnicidad no puede considerarse un fenómeno estático, sino más bien un proceso continuo (Gosselain, 2000: 188), "una dinámica en permanente status nascendi, que recoge, reelabora, reestructura e inventa representaciones y fuerzas sociales" (Cabezas, 2003). Es lo que se conoce como "etnicidad activa" o "etnogénesis continua", es decir, la constante reafirmación o rectificación de los valores identitarios de un grupo social a partir de una serie de estímulos internos y/o externos y dentro de un proceso histórico.

Que la "identidad colectiva" está en permanente cambio es algo que hoy en día nadie pone en duda. Otra cosa es que la Arqueología no lo haya reconocido como un fenómeno habitual en las sociedades pretéritas hasta hace relativamente poco, eso sí, más por sentido común que como resultado de una reflexión teórica profunda. Y es que si ya de por sí es complicado identificar los elementos que caracterizan a una determinada comunidad, su mutabilidad a lo largo del tiempo resulta desconcertante para el historiador. Es lo que podríamos definir mutatis mutandis como "principio de incertidumbre social" cuyas implicaciones en el campo de la Etnología todavía no han sido suficientemente valoradas. Así pues, podemos conocer en un momento preciso los signos predeterminados que definen a un grupo étnico en concreto, pero entonces habremos perdido la perspectiva diacrónica, porque tales elementos solo cumplen su función diacrítica en un espacio-tiempo limitado y no son aplicables a todo el proceso etnogenético. De lo contrario, daríamos por sentado que el grupo étnico ha permanecido inalterado en el tiempo, y bien sabemos que eso no puede ser cierto. Del mismo modo, si seleccionamos sólo aquellos elementos que presentan una continuidad temporal (por ejemplo, la lengua o ciertos aspectos de la cultura material), o lo que es lo mismo, los signos diacríticos más duraderos a través de los cuales se puede rastrear la singularidad de un grupo étnico a lo largo de su historia (aunque no tiene porqué tratarse de un ciclo vital), no se tendrán en cuenta las mutaciones, parciales y menos perceptibles, que le permiten reafirmar su identidad y adaptarla a las nuevas realidades geográficas o históricas. En otras palabras, cuando mayor sea la precisión con la que identifiquemos a un grupo étnico en un momento y lugar determinados, mayor será la dificultad para extrapolar sus valores identitarios a otros contextos espaciotemporales; y cuando con mayor precisión identifiquemos las pautas culturales que definen históricamente a un grupo étnico, mayores serán las dificultades para apreciar las particularidades del proceso etnogenético en cada estadio de la evolución.
Aunque sabemos que es, por "principio", imposible llegar a conocer al cien por cien las pautas que definen la identidad de un determinado colectivo y más aún su proyección temporal, debemos evitar por todos los medios caer en una posición nihilista. A pesar de que apenas se aprecien cambios en los elementos "objetivos" de su cultura (lengua, formas de organización sociopolítica, pautas de asentamiento, tradiciones técnicas, cultura material, etc.), no creemos que se deba obviar la complejidad del proceso de etnogénesis, sus implicaciones en el plano social y sus consecuencias históricas. Antes bien, teniendo en cuenta estas dificultades pensamos que una revisión crítica de las fuentes documentales, escritas y materiales, así como un uso discreto de la etnoarqueología y la etnología comparada, puede proporcionar las herramientas necesarias para adoptar un punto de vista emic que permita aproximarnos, siquiera levemente, a las transformaciones que se operan en la conciencia colectiva y sus repercusiones en la construcción ininterrumpida del ethnos.

\section{FAlsos AMIgos: LOS TESTIMONIOS LITE- RARIOS GRECOLATINOS}

Desde hace algunos años se viene denunciando reiteradamente los riesgos que entraña una lectura historicista y poco crítica de los testimonios literarios grecolatinos, principalmente en los estudios sobre geografía y etnología antiguas (García Moreno, 1989; García Quintela, 1991; Gómez Fraile, 1997 y 2001; Ferrer, 1998, entre otros). Nuestra tesis de licenciatura (García Fernández, 2003) y trabajos ulteriores (Ferrer y García, 2002; Ferrer y Prados, 2001-2002) han incidido sobre la especial complejidad de esta problemática en el ámbito de la Turdetania donde, paradójicamente, contamos con menos datos etnográficos en comparación con otras regiones de la Península Ibérica. No en vano, como tuvimos oportunidad de comprobar, son todavía frecuentes las investigaciones encaminadas hacia la reconstrucción del mapa paleoetnológico de la Península Ibérica a partir del uso de las fuentes escritas como complemento incontrovertible del dato arqueológico. Por otra parte, el estudio de las fuentes literarias sigue resultando imprescindible, pues los nombres con que conocemos comúnmente a la gran mayoría de los antiguos pobladores de Iberia fueron transmitidos por los geógrafos e historiadores de la tradición clásica. Es más, la creación de conceptos geopolíticos y geo-etnográficos destinados a la ordenación de los espacios peninsulares tras la conquista romana puede suponer, como veremos a continuación, la proyección de una relación dialéctica entre las comunidades indígenas y la 
potencia invasora que implique nuevas formas de etnicidad inducidas por los cambios en las circunstancias históricas.

Lo que se propone, en definitiva, es una lectura contextual de las fuentes escritas y una valoración de sus contenidos a partir de un análisis crítico de los factores que han actuado sobre su elaboración. Es preciso tener en cuenta, por tanto, la época en que fueron escritas las distintas obras, el género literario al que pertenecían, el grado de conocimiento geográfico y etnográfico existente en cada momento, la presencia o ausencia de autopsia, el contexto histórico de los autores, así como su formación literario/filosófica, sus prejuicios ideológicos y políticos, incluso sus propios avatares biográficos, con el fin de comprender de la mejor manera posible la perspectiva desde la cual proyectan su imagen sobre el objeto descrito (García Fernández, 2003: 19).

Tampoco podemos pasar por alto el contenido semántico del término $\varepsilon \theta v o \sigma$ que, al igual que

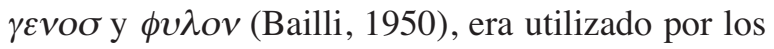
griegos con un sentido mucho más amplio que el que hoy día otorgamos al concepto "etnia" desde la moderna Antropología (Renfrew, 1998: 276, y más recientemente Cardete, 2004). Del mismo modo, los autores latinos empleaban indistintamente los términos gens y natio para hacer referencia de forma genérica a grupos humanos, ya se trate de un pueblo, nación, país o raza (Beltrán, 1986: 234). Evidentemente, un griego o un romano no podía tener en mente la misma idea que tenemos nosotros de "grupo étnico" ya que, por un lado, carecía de las herramientas necesarias para su identificación, delimitación y examen, es decir, de unos parámetros de análisis más o menos definidos y compartidos; mientras que por el otro, el conocimiento de la realidad indígena era algo que objetivamente no interesaba. No olvidemos que los geógrafos e historiadores de la Antigüedad carecían del principio que se conoce como "relativismo cultural", según el cual "toda pauta cultural es, intrínsecamente, tan digna de respeto como las demás" (Harris, 1990: 23-25)7. Como afirma García Moreno (1988: 84), "los civilizados observadores grecorromanos de las realidades hispánicas eran en gran medida incapaces de comprender la verdadera naturaleza de unos fenómenos que hundían sus raíces en unas estructuras socioeconómicas y políticas muy diversas a las suyas". Y es que, a pesar de algunos intentos por adoptar una

${ }^{7}$ Los antropólogos sostienen que "no hay cultura que sea mejor que otra, puesto que cada una de ellas es el resultado de tradiciones históricas que han sido aceptadas por la gente que vive dentro de ellas como su propio medio postura ecuánime y imparcial, como podemos comprobar por ejemplo en la obra de Posidonio de Apamea (Strasburger, 1965), la geografía y la historiografía helenísticas se encontraban generalmente determinadas por los paradigmas etnocentristas de la civilización grecolatina (Grilli, 1979; Dihle, 1990), ofreciendo en la mayor parte de las ocasiones una visión sesgada y distorsionada de la realidad. Así pues, la imagen que los autores antiguos transmiten de la Península no está condicionada únicamente por la realidad "objetivamente observable", sino también por el sujeto activo "que partiendo de ella y a través de un método de selección, jerarquización y ordenación de los datos recogidos, procede a su elaboración y transmisión", en función de sus propias necesidades (Ciprés, 1993: 270).

Todos estos razonamientos no deben, sin embargo, considerarse un pretexto para desestimar la validez de los testimonios literarios como fuentes de documentales. Es posible extraer informaciones más o menos veraces sobre aspectos substanciales de las poblaciones prerromanas de Hispania, como su nivel de desarrollo sociopolítico o el grado de urbanismo que llegaron a alcanzar, su relación con otras comunidades locales o foráneas, su orientación económica, recursos, vías de comunicación, incluso algunas costumbres y pautas culturales. Pero, ¿hasta qué punto los nombres que transmiten los autores clásicos hacen referencia inequívocamente a etnias propiamente dichas o a "pueblos" constituidos por unidades filiales menores? En general pensamos que para la Península Ibérica (Le Roux, 1995: 19-44) y, en particular, para la región turdetana (García Fernández, 2003: 182-188), se procedió a la creación de una serie de conceptos geo-etnográficos genéricos, simplificadores y homogenizadores, que permitieran la comprensión, ordenación y administración de los nuevos territorios que habían quedado bajo la esfera de control romano. Probablemente la práctica habitual de los geógrafos e historiadores grecolatinos fuera la de asimilar las regiones geográficas con cuadros étnicos en sentido amplio, dentro de los cuales se podían situar -aunque no necesariamente- una selección de "etnias" representativas a escala menor (Gómez Fraile, 2001).

Tal es el caso de la Celtiberia, donde bajo el término genérico de "celtíberos" fueron agrupadas varias ethne (Str. III.4.13; Apiano, Iberica, 44 y 48) a las que se reconocía rasgos lingüísticos, culturales

de vida. Para conseguir la objetividad, los antropólogos deben despojarse de todo tipo de prejuicios culturales y entender la cultura que estudian tal como la entendiesen los que viven en su seno" (Rossi y O’Higgins, 1981: 13). 
e históricos comunes (Ciprés, 1993: 285 ss.). Del mismo modo la Turdetania, que aparece en los distintos testimonios como un espacio geográfico con una funcionalidad político-administrativa e histórica propia (Cruz Andreotti, 1996: 63), se encontraba habitada según Estrabón (III.1.6 y III.2.13) no sólo por turdetanos (aunque éstos constituyeran el grueso de la población), sino también por bastetanos, oretanos, célticos e incluso púnicos (García Fernández, 2002: 193). Es posible incluso que, al igual que ocurre con los celtíberos, el término "turdetanos" haga referencia a un conjunto de unidades étnicas menores conscientes de cierta afinidad y de un origen común, y no a una etnia turdetana tal como hoy la entenderíamos (ibidem: 192). De hecho, no encontramos referencia alguna en la obra de Polibio - principal fuente de Estrabón- que aluda explícitamente a un ethnos tartesio o turdetano (García Fernández, 2003: 64). En la operatividad de este concepto geo-etnográfico jugaría también un papel esencial el interés de lo indígena por diferenciarse y destacarse ante el intruso, el romano, a través de un marco mucho más amplio que el del propio grupo étnico. Así pues, los turtos (como ellos posiblemente se autodenominarían) o turdetanos, conocedores de su parentesco, de su lengua y costumbres comunes, pudieron asumir consciente o inconscientemente que la creación de una nueva identidad era la única alternativa viable a la fragmentación política en la que se veía inmersa la región desde la desaparición de las aristocracias orientalizantes. La única manera de hacer frente común a la situación de conflicto y al choque cultural que se mantuvo durante los primeros siglos de la presencia romana.

Este fenómeno, que ha sido puesto en evidencia recientemente para otras poblaciones de la Península Ibérica (Moret, 2004), cuenta con paralelos etnográficos no sólo en sociedades desaparecidas, sino también en grupos étnicos contemporáneos, conocidos a partir de los estudios llevados a cabo durante la última centuria en las antiguas colonias

8 "The fact is that many tribes have come into existence in a similar way to the Luyia, through a combination of reasonable cultural similarity with colonial administrative convenience, which in more recent times has often coincided with people's own sense of need for wider levels of organization to enable them to exert more effective pressure on events" (Southall, 1970: 35).

9 Desde entonces el conflicto entre ambos grupos ha sido un fenómeno crónico, avivado con frecuencia por la intervención extranjera, sobre todo de Francia, que bajo la égida de la francofonía apoyó en 1975 al régimen dictatorial de los hutus radicales, a pesar de sus actuaciones europeas, principalmente del África negra. Algunas de las comunidades "tribales" descritas en la literatura antropológica surgen, de hecho, durante el periodo colonial, e incluso posteriormente, como resultado de la política neocolonial desarrollada por las potencias occidentales y, sobre todo, gracias a la labor de las ONG's y las grandes multinacionales, que han estimulado -no siempre de forma desinteresada- la conciencia étnica y el localismo como alternativa al modelo de "estado nación" (Campbell, 1997). Es el caso de los Baluyia, en el centro de la actual Kenia (Southall, 1970: 33-34). Al principio Kavirondo era únicamente un área geográfica y no hacía alusión a ningún grupo étnico en concreto. A principios del siglo XX la administración británica unificó las distintas tribus que habitaban la zona bajo un mismo étnico: Bantu Kavirondo. Con el tiempo, los nativos incluidos dentro de este marco extendieron el término avaluhia ("aquellos nacidos de la misma tribu") para autoidentificarse. Como resultado, entre 1935 y 1945 aproximadamente, el nuevo etnónimo Baluyia se fue imponiendo entre los miembros más jóvenes de la comunidad, dando lugar a una identidad étnica original anteriormente inexistente. Lo mismo se puede decir de los Sukuma y Nyamwezi en Tanzania o los Yoruba de Nigeria, entre muchos otros ${ }^{8}$. Un ejemplo reciente y especialmente dramático es el conflicto entre los Hutus y los Tutsis en la región de los Grandes Lagos, resultado no tanto de la rivalidad ancestral entre la mayoría hutu -agricultores sedentarios- y la minoría tutsi - dedicada a la ganadería- desde la aparición de esta última en la región durante el siglo $\mathrm{XV}$, sino sobre todo de la política llevada a cabo por el gobierno colonial y las potencias occidentales al privilegiar a la minoría tutsi y convertirla en elite ${ }^{9}$.

En consecuencia, podemos decir que la importancia de los testimonios literarios reside precisamente en participar de este doble fenómeno. Por un lado, los geógrafos e historiadores de la Antigüedad contribuyeron a la creación de esquemas geo-etnográficos reduccionistas y homogeneizadores que

inaceptables frente a los tutsis, que se habían convertido anglófonos. Por su parte, "la implicación americana en conflictos étnicos de Los Grandes Lagos parece inscribirse en el marco de la lucha de influencia entre los Estados Unidos y Francia. Los Estados Unidos están determinados a no dejar a Francia jugar el papel de gendarme en África, y tratan de crear nuevos gendarmes africanos aliados. (...) Para ello, se utiliza esta región para experimentar un modelo de destrucción de Estados naciones, creando nuevas agrupaciones étnicas satélites" (Gasana, 1997). 
facilitaran la ordenación de los territorios conquistados por parte de la administración romana; mientras que, por el otro, constituían un reflejo del proceso a través del cual las poblaciones del área meridional de la Península Ibérica -no sólo los turdetanos, sino posiblemente también los púnicos, bastetanos, etc.se redefinieron a sí mismas, modificando en parte sus parámetros identitarios, con el fin de contrarrestar las consecuencias que entrañaba su integración en el sistema provincial romano.

\section{UNA RELACIÓN DIFÍCIL: ETNIAS Y CULTU- RA MATERIAL}

Es precisamente una lectura historicista y poco crítica de las fuentes literarias, unido al análisis positivista y estilístico del registro material, lo que ha llevado tradicionalmente a la inclusión de los turdetanos dentro del ámbito de la "pueblos iberos". Con mejor fortuna, los estudios sobre la Iberia púnica se han centrado en la caracterización de sus rasgos culturales gracias, entre otras razones, a la existencia de un repertorio material amplio y diversificado con paralelos en el Mediterráneo Central y Oriental, al reconocimiento de una koiné linguiística y cultural a partir de la documentación epigráfica y las fuentes literarias, así como a la percepción autoconsciente de un origen común. No obstante, aún se sigue considerando el mundo púnico peninsular como un todo uniforme, sin tener en cuenta las particularidades locales surgidas de diferentes contextos ecológicos, poblacionales, como de las circunstancias políticas, sociales y económicas que determinan el desarrollo de procesos etnogenéticos diferenciados ${ }^{10}$. Por el contrario, los estudios sobre el iberismo en la Alta Andalucía se han ocupado, con mayor o menor éxito, de identificar y delimitar las distintas etnias históricas a partir de la distribución de determinados elementos exclusivos de su cultura material, como pueden ser las tumbas de cámara y las cajas funerarias de piedra en el área bastetana (Almagro, 1982), o la escultura zoomorfa en el ámbito oretano y turdetano (Lacalle, 1996).

\footnotetext{
${ }^{10}$ En los últimos años la investigación ha venido mostrando un creciente interés por las distintas formaciones políticas que surgieron del desmembramiento del proyecto colonial fenicio (Arteaga, 1994), la participación más o menos directa de Cartago en la configuración del mapa político sudpeninsular (De Frutos, 1991; López Castro, 1991 a y b; González Wagner, 1994) y la perduración del substrato púnico durante los primeros siglos de la presencia romana (por ejemplo, Bendala, 1982; García Moreno, 1992; López Castro, 1995). En cambio, son
}

Como decimos, desde los inicios de los trabajos arqueológicos en el Sur peninsular y coincidiendo con el desarrollo de la Arqueología como disciplina científica, los distintos investigadores han considerado sistemáticamente el mundo turdetano como un apéndice meridional de la "cultura ibérica". Este planteamiento fue seguido por Bosch Gimpera en su Etnología de la Península Ibérica (1932) y, posteriormente, por Pericot (1950), García y Bellido (1963) o Maluquer (1970), continuando con pocos matices hasta las últimas décadas del siglo $\mathrm{XX}$ (Bendala, 1981 y 2000; Ruiz y Molinos, 1993, entre otros). El panorama comienza a cambiar, no obstante, a partir de los trabajos de Carriazo (1973) y sobre todo con Pellicer (1976-1978: 21), para quién "la iberización de Andalucía occidental es simplemente una consecuencia de la adaptación por los tartesios del bronce final de unas formas materiales y espirituales importadas fundamentalmente por los fenicios, colonizadores del siglo VIII a. de J.C., con alguna aportación del mundo griego y con ciertas influencias intermitentes del mundo atlántico y de la Meseta". Desde entonces y hasta ahora, aunque todavía hay quienes se resisten a abandonar el paradigma "ibérico", es cada vez más frecuente el uso de los términos "turdetanos" y "cultura turdetana" y se da por sentada la singularidad de los procesos de transformación que afectan a las sociedades indígenas del valle del Guadalquivir durante la II Edad del Hierro (García Fernández, 2002b: 222).

Escacena (1989), por ejemplo, ve en la cultura turdetana una evolución de las comunidades indígenas del Bronce Final que, una vez se abandonan los hábitos adoptados por la elite social durante el periodo Orientalizante, aquellos que no habían sido asimilados por el resto de la población, recuperan su "identidad perdida" mediante un retorno a las costumbres ancestrales. Estas costumbres, a las que habría que sumar la lengua y el mundo de las creencias, ponen en relación a los turdetanos con los grupos que ocupaban la fachada atlántica durante la Prehistoria y no con los que comúnmente se conocen como "Iberos". Del mismo modo, Ruiz Mata

prácticamente inexistentes los estudios encaminados a la definición de las particularidades étnicas que distinguían a unos grupos de otros a partir del análisis en conjunto de la documentación arqueológica y las fuentes literarias. No ocurre así con la Numismática, que propone desde hace más de una década la existencia de identidades bien definidas no sólo a nivel político, sino también desde el punto de vista étnico y cultural (García y Bellido, 1993; Domínguez Monedero, 2000; Chaves Tristán, 2000, entre otros). 
(1997 y 1998) afirma que los turdetanos no son más que los continuadores de los tartesios, cuya cultura surgió como resultado de las nuevas condiciones económicas y políticas que sucedieron a la crisis del siglo VI. La Turdetania constituye, pues, "una realidad distinta a otros pueblos 'ibéricos' de la misma época, aunque en muchos casos con raíces comunes provenientes desde la época Orientalizante y su expansión hacia el interior y costa peninsulares" (Ruiz Mata, 1998: 162). No obstante, al contrario de lo que opina Escacena, este investigador reconoce la génesis de la "cultura turdetana" en la síntesis del elemento oriental con la población indígena en el ámbito de la bahía de Cádiz. Si no he entendido mal, lo que en realidad piensa es que la población local, tras varios siglos de convivencia, habría sucumbido al impacto de la presencia de comunidades foráneas con un grado de desarrollo "superior", dando lugar a una nueva realidad poblacional que no es ni fenicia ni tartesia, sino turdetana. Así pues, prescindiendo de cualquier otro factor de diferenciación y sobre la base de un repertorio cerámico común, Ruiz Mata propone un mestizaje étnico y cultural en el que los rasgos particulares acaban diluyéndose hasta hacerse prácticamente imperceptibles. Ello le ha llevado a identificar indiscriminadamente a las poblaciones púnicas de la costa con los grupos étnicos de raigambre indígena mencionados por los testimonios literarios de la Antigüedad, hasta el punto de considerar Doña Blanca, una ciudad fenicia situada en la desembocadura del río Guadalete, como el paradigma de la ciudad turdetana (Ruiz Mata, 1998: 186). Si tomamos al pie de la letra a Estrabón (III.2.13), el hecho de que muchos fenicios habitaran la Turdetania no significan que fueran turdetanos, sino precisamente todo lo contrario, que existían suficientes diferencias como para que los escritores griegos y latinos se percataran de ello. La hipótesis de Ruiz Mata se contradice, además, con los paralelos etnográficos aportados por la Antropología, ya que lejos de desdibujar las fronteras etnosociales, el contacto estrecho entre diferentes grupos no hace más que intensificar sus propias señas de identidad (Cabezas, 2003). Es decir, independientemente de que se asimilen o no determinados elementos de la cultura material, lo que realmente estimula el contacto interétnico es la toma de conciencia de la alteridad y el reforzamiento de los argumentos autoexcluyentes o la creación de nuevos signos diacríticos de diferenciación que pueden o no dejar una huella evidente en el registro arqueológico.

De nuevo son los estudios de Escacena (1989, 1992 y 2004) los que permiten elaborar un discurso crítico sobre las posibilidades que ofrece la Arqueología a la hora de identificar grupos étnicos en el ámbito de la Protohistoria andaluza. En su opinión, ni la vajilla cerámica, ni el urbanismo, ni las formas constructivas, ni las técnicas metalúrgicas pueden considerarse en sí mismos parámetros de diferenciación étnica, dado que se trata, por lo general, de logros adaptativos con un reducido contenido ideológico que traspasan con frecuencia las fronteras lingüísticas, políticas, geográficas y étnicas, para convertirse en elementos comunes a un conjunto amplio de comunidades contemporáneas. Por el contrario, la filiación de los distintos pueblos prerromanos que habitaban la Península Ibérica debería hacerse, más bien, "a partir de cuestiones referidas a las pautas conductuales animológicas más que desde la cultura material (...). Desde este punto de vista, la lengua, la religión, los ritos funerarios, los sistemas totémicos, la organización familiar y social, las formas de posesión del territorio histórico, la conciencia de pueblo plasmada en los etnónimos autoimpuestos, los sistemas económicos, etc. se convierten en la carta de presentación de los pueblos, por encima desde luego de la tecnología, que no es más que un mecanismo material de adaptación a unas circunstancias geográficas determinadas y a un nicho ecológico concreto" (Escacena, 1992: 323). Todo ello deja un estrecho margen de actuación al arqueólogo, al menos en lo que se refiere al mundo turdetano, donde la ausencia de enterramientos, la parquedad de documentos escritos -en su mayoría epígrafes monetales de época romana- y las escasas evidencias de cultos, creencias y mitos dificultan enormemente la tarea de localizar e identificar los signos diacríticos empleados consciente o inconscientemente por las distintas comunidades para expresar su identidad. En tal caso, únicamente la referencia a un "pueblo" turdetano en las fuentes literarias grecolatinas permitiría, con las salvedades expuestas en el apartado anterior, suponer la existencia de uno o varios grupos étnicos en la Baja Andalucía sucesores de la antigua "civilización" tartésica y diferentes a otros grupos contemporáneos como los púnicos o los ibero-bastetanos. ¿Con qué evidencias contamos entonces para hablar de la existencia diferentes etnias en la Turdetania? Y lo que no es menos importante, ¿hasta qué punto es posible explorar la etnicidad desde una perspectiva arqueológica? Ello nos introduce de lleno en la cuestión que ocupa este apartado, la relación ambigua entre la etnicidad y la cultura material.

Según J.M. Hall (1998: 267), los grupos étnicos pueden comunicar su identidad a través de símbolos, consciente o inconscientemente seleccionados de un amplio repertorio cultural y a los que se dota de una significación "emblemática". Del mismo modo S. Jones (1997) -basándose en buena medida 
en el trabajo de Bentley (1987)- afirma que, si bien la distribución espacial y temporal de determinados artefactos no definen necesariamente las fronteras de un grupo étnico, ello no impide que la cultura material se encuentre frecuentemente implicada en el reconocimiento y la expresión de la etnicidad. Así pues, se acepta que ciertos aspectos de la cultura material pueden estar a menudo involucrados en la construcción autoconsciente de la identidad y en la justificación y negociación de las relaciones étnicas. No obstante, frente a la tesis de Hall (1997), que se centra exclusivamente en los aspectos instrumentales de la etnicidad, es decir, aquellos encaminados a satisfacer intereses específicos, Jones opina que la selección de determinadas formas y estilos en la cultura material como marcadores étnicos no es un proceso arbitrario ni mecánico (Jones, 1997: 120; ver Bentley, 1987: 33 y 36). Al contrario, la cultura material es una parte esencial de las prácticas sociales dentro del grupo y, por lo tanto, participa activamente en la producción de representaciones discursivas de la identidad (Jones, 1998: 273). Lo que quiere decir que los significados no están fijados de forma permanente, sino que se encuentran constantemente sujetos a reelaboraciones y transformaciones. De este modo, al igual que los valores identitarios de los grupos étnicos van mutando a lo largo del tiempo y el espacio, consecuentemente los rasgos de la cultura material implicados en la significación y estructuración de las relaciones étnicas pueden variar en diferentes contextos espacio-temporales, así como en relación a diferentes formas y escalas de la interacción social. Es más, unos mismos ítems que se encuentren ampliamente distribuidos y sean usados en diversos contextos sociales e históricos, pueden ser consumidos de diferentes maneras y llegar a estar implicados en la generación y significación de una variedad de expresiones de etnicidad (Jones, 1997: 122-124). Lógicamente, "sobre esta base no puede asumirse a priori que las semejanzas en la cultura material reflejen la presencia de un determinado grupo de personas en el pasado, un índice de interacción social, o un marco normativo compartido" (Jones, 1997: 126). Los grupos étnicos no deberían verse, por tanto, como entidades monolíticas productoras de un repertorio definido de artefactos sometidos a cambios graduales a lo largo del tiempo. En tal caso se corre el riesgo de confundirla con una "cultura arqueológica". La relación entre las etnias y la cultura material es en realidad un proceso activo a través del cual una serie de manifestaciones materiales de los procesos sociales se convierten en símbolos étnicos, esto es, en transmisores de la identidad, que pueden ir modificándose o sustituyéndose por otros diferentes en función de la propia dinámica etnogenética. La cuestión es averiguar qué ítems o qué aspectos de la cultura material, consciente o inconscientemente seleccionados, son los que reflejan en cada momento esta identidad. Ello nos lleva a la siguiente pregunta, ¿puede la cultura material por sí sola proporcionar bases sólidas para la delimitación, en las coordenadas espacial y temporal, de un grupo étnico?

Según Jones (1997: 125-126; 1998: 272), un análisis diacrónico de los contextos culturales a partir de una variedad de fuentes y clases de datos es esencial para comprender la expresión de la identidad a través de la cultura material y su uso en la definición de límites étnicos. Un adecuado conocimiento de la organización social también es importante, ya que "la etnicidad es tanto una construcción transitoria de repetidos actos de interacción y comunicación, como un aspecto de la organización social que puede llegar a estar institucionalizado en diferentes grados, y en diferentes formas en diferentes sociedades" (Jones, 1997: 126). Sin embargo, ante la eventual ausencia de documentación escrita, y sobre todo si se trata de sociedades ágrafas, no existen referencias "objetivas" (es decir, subjetivas respecto al objeto de estudio) que permitan al investigador distinguir símbolos étnicos de otras manifestaciones de la identidad, como por ejemplo el género, la edad, la identidad política, etc. (Hall, 1998: 267). G. Ruiz Zapatero y J.R. Álvarez Sanchís (2002), siguiendo de cerca la tesis de Hall (1997: 142 ss), reconocen que sólo la combinación de las fuentes literarias con la documentación arqueológica puede dar una visión aproximada sobre la identidad étnica de las sociedades del pasado. Resulta evidente, por tanto, la dificultad que entraña aislar grupos étnicos en sociedades prehistóricas o en culturas que, aún conociendo la escritura, no han dejado testimonios sobre sus orígenes, valores, creencias, etc. La única solución pasaría entonces por estudiar cómo se comporta la cultura material en la definición de los grupos étnicos de la Antigüedad que contaban con documentos escritos -como se ha hecho recientemente para la antigua Grecia (Hall, 1997)-, al aportar una evidencia explícita sobre los indicadores materiales que se empleaban en otras sociedades contemporáneas con un nivel de desarrollo similar. Dado que la mayor parte de estos indicadores, como la indumentaria, el peinado, el uso de pinturas corporales, abalorios, tatuajes, etc. apenas dejan huella arqueológica, no queda más remedio que recurrir a la ayuda de los paralelos etnográficos para adivinar qué de la cultura material adquieren un valor emblemático y se convierten en signos externos de la identidad (Ruiz y Álvarez-Sanchís, 2002: 256). 
Sin embargo, el uso de analogías etnográficas puede resultar incongruente si nos aferramos a una visión constructivista o subjetivista de la etnicidad, como la desarrollada por Jones, ya que cada grupo étnico expresaría su identidad de manera diferente a los demás a través de una serie de elementos exclusivos cuyo significado ha sido adquirido dentro de un contexto histórico y social determinado. Si partimos unicamente de una interpretación contextual de la etnicidad, en la que solamente un análisis del contexto social y conceptual permite comprender la manera en que los objetos se implican en la "construcción” de la identidad (Hodder, 1988: 144 ss.), difícilmente podrá ser de utilidad el recurso a manifestaciones materiales similares, o con funciones análogas, que han tenido su origen en otros contextos culturales ${ }^{11}$. Aunque tampoco se debe caer en un relativismo radical, puesto que una lectura contextual, por sí sola, sobre todo si se trata de sociedades ágrafas, no es capaz de extraer el significado de los códigos que se manifiestan en la cultura material y que pueden quedar ocultos a la mirada del arqueólogo, bien porque hayan desaparecido, bien porque se carezca de referencias para su interpretación.

La otra opción es recurrir a la Etnoarqueología como método (González Ruibal, 2003: 116), pero se corre el riesgo de caer en una visión instrumentalista $-\mathrm{o}$ adaptativa - de la identidad étnica, sobre todo por su larga tradición como "teoría de alcance medio" dentro de los parámetros de la Nueva Arqueología y la Arqueología Procesual (Hernando, 1995). Ello nos obligaría a suponer la existencia -dentro de una etnicidad socialmente construida y subjetivamente percibida (Hall, 1997: 19)- de ciertos elementos recurrentes utilizados de forma generalizada como marcadores étnicos (territorio, parentesco, lengua, etc.) y, en consecuencia, a buscar pautas que permitan establecer patrones de comportamiento transculturales con el fin predecir, en cada caso, los medios de expresión de la identidad, así como la relación entre el comportamiento de las sociedades pasadas y su cultura material.

${ }^{11}$ Por ejemplo, a nadie se le ocurre pensar hoy en día que las cráteras áticas documentadas en las necrópolis de la Alta Andalucía y el sur de la Galia pudieran tener para sus poseedores la misma significación que para los griegos continentales. Aunque su carácter aristocrático en ambos casos queda fuera de toda duda, su papel como vehículo de expresión de unos valores colectivos se encuentra determinado por el contexto histórico y social que le otorga significado. Al menos que yo se sepa, no se ha documentado hasta ahora ninguna crátera en contextos funerarios propiamente griegos, salvo casos muy
¿Cuál sería entonces el camino más adecuado para este tipo de estudios? Una solución intermedia pasaría por aceptar las ventajas de la analogía etnográfica, aún asumiendo el carácter aproximativo de sus resultados y su incapacidad para predecir situaciones similares en contextos sociales y culturales diferentes. Ello nos permitiría seguir las pistas de algunos elementos que, por sus características, no han dejado huella en el registro arqueológico, o bien de determinados aspectos de la cultura que para nosotros han pasado desapercibidos pero que jugaron un papel decisivo en la construcción de la identidad, tanto en sociedades pasadas como en las presentes. A partir de este punto, efectivamente, sólo una lectura contextual de las diferentes manifestaciones culturales (materiales o no), dentro de los procesos sociales e históricos en los que se encuentran insertas, podrá ayudarnos a definir los medios a través de los cuales los pueblos de la antigua Turdetania expresaban su(s) identidad(es) y cómo fueron evolucionando a lo largo del tiempo.

No olvidemos que la etnicidad es una construcción social y, como tal, se encuentra sometida a una constante reelaboración en estrecha conexión con las coyunturas históricas. La etnicidad es el resultado del contexto social y su circunstancia, podríamos decir parafraseando a Ortega y Gasset. No se trata, por tanto, de conocer únicamente los indicadores étnicos de los distintos grupos que habitaban la Turdetania y su evolución a lo largo de la Edad del Hierro, sino la manera en cómo interactuaron entre sí en un proceso discursivo a través del cual se convertían eventualmente en elementos de adscripción y exclusión.

\section{INDICADORES ÉTNICOS E IDENTIDADES CULTURALES EN LA TURDETANIA: PROPUES- TAS A DEBATE}

Dado lo reducido del espacio disponible nos centraremos en los dos principales grupos que habita el valle del Guadalquivir en época prerromana: los tartesio-turdetanos y los púnicos occidentales, dejando

excepcionales en Magna Grecia y Sicilia (de la Genière, 1987); del mismo modo, aunque las aristocracias "ibéricas" se vieran identificadas en las escenas heroicas representadas en los grandes vasos (Jiménez Flores, 2002: 375), aunque las elites helenizadas del sur de la Galia introdujeran el culto simposiástico en el ritual funerario (Bats, 2002: 292), en ninguno de los casos se llegó a entender completamente el sentido original y los argumentos iconográficos desarrollados en el objeto en cuestión. 
para otra ocasión a los célticos de la Beturia y a las poblaciones "ibéricas" de la Alta Andalucía. Para ello se hará hincapié en algunos de los elementos que podrían haber sido usados con mayor frecuencia o durante más tiempo como medios de expresión de la identidad, ya sea consciente o inconscientemente. Del mismo modo, plantearemos las dificultades que entraña este estudio en determinados ámbitos y periodos cronológicos, a la vez que propondremos posibles líneas de investigación. Todo ello nos permitirá caracterizar a grandes rasgos los grupos étnicos que habitaban el Bajo Guadalquivir durante la II Edad del Hierro, al menos en determinados aspectos de su cultura, aquellos que de una manera u otra han llegado hasta nosotros.

\section{A) Los TURDETANOS}

Como acabamos de ver, los turdetanos no cuentan con elementos materiales que permitan diferenciarlos de otras comunidades que habitaban el sur de la Península, como los púnicos o las tribus "célticas" mencionadas por las fuentes literarias. Se trata ciertamente de una realidad histórica (García Fernández, 2003), pero carecemos de criterios para poder definirla desde una metodología arqueológica (Downs, 1998: 52). Ello se debe, en parte, a la asimilación de los logros tecnológicos (como el modelado a torno, la metalurgia del hierro, etc.) introducidos por los fenicios durante el periodo Orientalizante e incorporados de forma definitiva a los procesos productivos (Escacena, 1992). A ello hay que añadir el progresivo retroceso de la cerámica a mano, íntimamente ligada a las formas de vida de las poblaciones autóctonas a finales de la Edad del Bronce, frente a las importaciones fenicias y las cerámicas a torno de producción local.

Ello no excluye que al menos durante los siglos VII y VI a.C. siguieran apareciendo, junto a los platos de barniz rojo, urnas y cuencos a torno, cerámicas a mano de tradición indígena, principalmente cazuelas carenadas y copas con decoración de retícula bruñida, en los principales poblados del ámbito tartésico, como La Saetilla (Murillo, 1994), San Bartolomé de Almonte (Ruiz y Fernández, 1986) o Cerro Macareno (Pellicer y otros, 1983). Su predominio en los asentamientos de tercer orden -aldeas y factorías agrícolas- junto a los pithoi y otros gran-

12 Prueba de ello es la ausencia de cerámica gris en las necrópolis fenicias, como Trayamar o Laurita, donde se impone claramente la cerámica de engobe rojo, dotada de una significación especial en los contextos funerarios (Jiménez Flores, 2002: 187). Por el contrario, sí aparece des vasos de almacenamiento realizados a torno (Murillo, 1994; Ferrer y Bandera, 2005), puede estar indicando el apego de una gran parte de la población, aquella que no tenía acceso a los bienes de prestigio, al repertorio común a mano $\mathrm{y}$, en particular, a la vajilla que durante siglos se había venido utilizando no sólo en el ámbito doméstico, sino posiblemente también en contextos rituales. En este sentido resulta llamativo que a finales del siglo VIII, y sobre todo a principios del siglo VII, surgiera en el ámbito colonial un tipo de cerámica, conocida como "gris orientalizante", que imitara a torno una buena parte de las formas abiertas que anteriormente (y contemporáneamente) se realizaban a mano (Vallejo, 1998 y 1999). Nos encontramos, por tanto, ante un producto realizado en alfares fenicios destinado a satisfacer la demanda indígena de una vajilla de uso cotidiano (Vallejo, 1999: 88), a partir de prototipos locales pero con tecnología oriental (Belén, 1976; Roos, 1982). El éxito de estas producciones entre la población indígena viene demostrada por el hecho de que su presencia en los asentamientos tartésicos no sólo es abundante, sino en ocasiones mayoritaria, mientras que su proporción es menor en los establecimientos fenicios, donde seguramente eran producidas ${ }^{12}$. Esta afinidad con los modelos locales afecta incluso a la decoración que, aunque minoritaria, repite las técnicas, los temas y la organización compositiva utilizada en las cazuelas y copas de la zona de Huelva y el Bajo Guadalquivir durante el Bronce Final y el periodo Orientalizante, entre las que predomina el reticulado bruñido (Vallejo, 1997 y 1999). En opinión de López Roa (1978: 159), "la presencia de cerámicas grises fabricadas a torno con decoración bruñida puede interpretarse como continuación de la técnica del bruñido aplicado a la decoración sobre piezas más evolucionadas y cronológicamente más tardías", es decir, un fenómeno de "hibridación" a través del cual se introducen nuevas técnicas de fabricación que no alteran sustancialmente los modelos formales y decorativos de la tradición local (Roos, 1982; Vallejo, 1999).

No queremos decir con todo esto que la cerámica a mano, especialmente la decorada, deba ser considerada como una expresión objetiva de la identidad tartésica (o turdetana), ya que ante todo se trata de una tradición tecnológica, sino que su preferencia

en los santuarios orientales y orientalizantes del Bajo Guadalquivir, como Carmona (Belén y Escacena, 1997) o Montemolín (Mancebo y otros, 1992; Mancebo, 1994), donde convive con las producciones a mano. 
entre la población indígena podría estar sugiriendo una vinculación entre su uso, estrechamente ligado a lo cotidiano, y el sentimiento de pertenencia a un grupo, diferente a los colonizadores y muy probablemente también a las elites, con quienes habían dejado de existir intereses comunes. La aparición en contextos claramente coloniales, como Castillo de Doña Blanca (Ruiz Mata, 1995), El Carambolo (Carriazo, 1973) o incluso Montemolín (Bandera y otros, 1993), de una considerable cantidad de cerámicas hechas a mano, así como de cerámicas grises orientalizantes, es una prueba de la complejidad de este fenómeno, que requiere de un estudio monográfico no sólo en el Bajo Guadalquivir, sino también en la costa atlántica peninsular ${ }^{13}$.

En cualquier caso a partir del siglo VI y principios del V a.C. la cerámica gris desaparece por completo del registro material, mientras que los recipientes a mano quedan paulatinamente excluidos de los ámbitos de consumo hasta prácticamente extinguirse a inicios de la siguiente centuria. En contraposición, se imponen las cerámicas a torno con cocciones oxidantes o alternas y decoración pintada monocroma, o bien sin decoración, con engobes claros o anaranjados. A partir de este momento se inicia un periodo que podríamos denominar de stasis formal en el cual se fija, con pocos cambios, un repertorio tipológico donde se integran las formas y decoraciones del mundo próximo-oriental con los modelos de tradición local (Escacena, 1987), que otorgarán al conjunto un marcado cariz arcaizante, sobre todo si lo comparamos con la evolución sufrida por otros repertorios peninsulares (Escacena, 1989: 461). Esta formalización implica necesariamente una selección, en el sentido evolutivo de la palabra, de los tipos que mejor se adaptan a las exigencias de las poblaciones a las que estaban destinadas, es decir, a las actividades domésticas o productivas desempeñadas, así como posiblemente tambien a su horizonte mental y animológico. La vajilla resultante se caracteriza tanto por el reducido número de formas, como por la monotonía de sus variantes que, una vez establecidas, van a evolucionar poco o nada a lo largo de la II Edad del Hierro e incluso durante los primeros siglos de la presencia romana. Ello dificulta enormemente cualquier tentativa de clasificación cronológica, a no ser que se cuente con otros elementos de datación relativa dentro de los contextos arqueológicos exhumados, como las ánforas púnicas, la cerámica griega de bar-

13 Trabajo que fue emprendido a finales de los años noventa por I. Vallejo Sánchez y que ha visto sus primeros fru- niz negro o las importaciones campanas. Sin embargo el problema que aquí nos ocupa es de otra índole y surge de la incapacidad de la cerámica turdetana para ser utilizada como un indicador étnico, ya que "la dispersión de sus formas y de sus decoraciones trasciende las propias fronteras de los turdetanos, ya sean las cronológicas ya las geográficas" (Escacena, 1989: 460).

Nacida, como acabamos de ver, de la interacción entre las sociedades indígenas y los colonizadores en el ámbito tartésico, la cerámica "turdetana" sigue una evolución paralela a la de las comunidades púnicas del Bajo Guadalquivir y a la de los talleres "ibéricos" de Andalucía Oriental, con las que guarda evidentes concomitancias (Pereira, 1989). Así pues, aunque creemos posible hablar de vajillas típicas turdetanas, "ibéricas" o púnico-gaditanas, con algunos rasgos particulares, tanto en la morfología de los recipientes como en su decoración (Ferrer y García, 2002: 146), resulta complicado, por no decir imposible, ponerlas en relación con un grupo étnico en concreto. Sólo determinadas familias cerámicas, como las ánforas o la vajilla tipo "Kouass" en el ámbito púnico (Niveau, 2004; Niveau y Ruiz, 2000), o bien ciertas formas y decoraciones propias de la Alta Andalucía (Pereira, 1988 y 1989), permiten a grandes rasgos definir lo que no es turdetano frente al repertorio, siempre monótono, que caracteriza a las poblaciones del Bajo Guadalquivir. Pero no hay que olvidar que la intensificación de las relaciones comerciales conlleva inevitablemente la movilidad de estas especies, que son distribuidas y consumidas en ámbitos diferentes a su contexto de origen, tanto productivo como social.

Lo mismo se puede decir (aunque no nos detengamos en ello) de otros aspectos materiales como la metalurgia, el urbanismo o las técnicas constructivas (Escacena, 1989 y 1992), que han sido utilizados tradicionalmente, como vimos en el apartado anterior, para caracterizar una "cultura turdetana" continuadora del periodo Orientalizante Tartésico y, en el peor de los casos, como prolongación de la "cultura ibérica" (García Fernández, 2002; Ferrer y García, 2002). ¿Qué es lo que nos queda entonces? Volviendo con la tesis de Escacena (1992: 323), la identidad de los pueblos prerromanos del área sudpeninsular sólo podría reconocerse a partir de los comportamientos relacionados con el mundo de las creencias, o lo que es lo mismo, con los horizontes mentales que subyacen a las distintas "culturas

tos en distintas publicaciones, algunas de las cuales apuntamos en el texto. 
arqueológicas" y en los cuales se encuentran representados no sólo las creencias religiosas o las costumbres funerarias, sino también la lengua, las relaciones de parentesco, las genealogías, la cosmovisión, etc. Sin embargo, como también tuvimos oportunidad de comprobar, se trata por lo general de aspectos que son difíciles de advertir a través de la metodología arqueológica, hecho que se agrava aún más en el caso turdetano, donde carecemos de necrópolis, representaciones iconográficas, lugares de culto más o menos evidentes $\mathrm{y}$, sobre todo, de testimonios escritos que describan el universo que se esconde detrás de estas manifestaciones.

El panorama se presenta, pues, lleno de obstáculos, aunque en nuestra opinión todavía se pueden proponer algunas líneas de trabajo. Para empezar tenemos la propia ausencia de documentación, que genera una imagen en negativo de lo que podría ser un comportamiento homogéneo compartido por una parte de las poblaciones que habitaban la Baja Andalucía y que viene a coincidir con aquellos a los que nosotros otorgamos el apelativo genérico de "turdetanos". Es decir, es posible diferenciar a un grupo de comunidades -llamémosle turdetanosque se distinguen de sus vecinos (púnicos, bastetanos, etc.) precisamente por lo que no tienen o, mejor dicho, por lo que no expresan o expresan de otra manera. Ello no quiere decir que estas manifestaciones deban constituir necesariamente elementos operativos en la construcción de una determinada identidad, pues no sabemos hasta qué punto eran conscientemente utilizadas por sus agentes como criterios de adscripción y/o exclusión. En cualquier caso, ello deja la puerta abierta hacia otras vías de expresión de la etnicidad que, debido a su escasa o nula representabilidad material, han pasado generalmente desapercibidas a los arqueólogos o no han sido aún documentadas. Nos estamos refiriendo, por ejemplo, a determinados tipos de culto, como el culto a los antepasados, que podría haber tenido un carácter anicónico; o bien a santuarios relacionados con elementos de la naturaleza, como cuevas, manantiales, fuentes de agua, bosques, etc. La difícil identificación de estos loca sacra en un área tan topográficamente homogénea e intensamente antropizada como el Bajo Guadalquivir ha contribuido a que apenas se le haya prestado atención desde la Arqueología, a pesar de contar con paralelos en

14 Un caso llamativo es el de las fuentes de aguas medicinales, cuya veneración -ya en época romana- ha quedado testimoniada por la presencia de sendos epígrafes dedicados a Salus: uno en Marchena (CIL II 1391), donde Madoz (1849) menciona la existencia de manan- otras comunidades contemporáneas del ámbito indoeuropeo (Marco, 1986), e incluso también, con todas las salvedades que afectan a las creencias y el ritual, en el ámbito cultural ibérico (Burillo, 1997; Domínguez Monedero, 1997) ${ }^{14}$. Conviene recordar también la posible costumbre de arrojar los cadáveres a los ríos, que se ha propuesto como solución a la ausencia de registro funerario en la fachada atlántica peninsular tanto en el Bronce Final como durante la II Edad del Hierro (Belén y Escacena, 1991; Escacena y Belén, 1994).

Del mismo modo, la pertenencia a un determinado grupo étnico se puede expresar, al igual que ocurre con los grupos de edad o género, a través de atributos externos como el peinado, la barba, el color de la ropa (Barber, 1999; Gage, 1999), los tatuajes, adornos o simplemente la forma de vestir (Eicher, 1995), imposibles de reconocer a menos que se cuente con representaciones figuradas. En último lugar, merecen una especial atención algunos aspectos relacionados con la organización social, concretamente las relaciones basadas en vínculos de parentesco, cuya perduración durante los siglos I y II d.C. parece fuera de toda duda (Chic, 1998 y 2001). El estudio de los patrones de asentamiento, la jerarquización del hábitat, los modelos de explotación económica, los sistemas de dependencia (como la "servidumbre comunitaria"), así como de la onomástica indígena y los modos de filiación, puede constituir en el futuro una fuente de información de primer orden sobre los procesos sociales en los cuales se generan los vínculos identitarios de los grupos turdetanos.

En este sentido, la conquista romana supuso un acicate definitivo para la configuración de una "identidad turdetana", tanto en lo que se refiere a su proyección externa, es decir, la visión homogenizadora que se elabora desde otras culturas -en este caso la griega y la romana- sobre unas comunidades que muestran ciertas afinidades (ethne); como a la propia imagen que adquieren de sí mismos los turdetanos ante la nueva situación. Así pues, el concepto "Turdetania", al igual que "turdetanos", no es más que el resultado de un proceso comprensión e interpretación llevado a cabo por la geografía e historiografía helenística de unos espacios que habían ya entrado a formar parte del Imperio Romano (García Fernández, 2002). Al mismo tiempo, el cho-

tiales de aguas minerales sulfurosas (Ordóñez, 1996), y otro en Estepa (CIL II 1437), siendo especialmente abundantes en la zona lusitana y en el noroeste de la Península Ibérica (Haba y Rodrigo, 1990; Rodrigo y Haba, 1992; Díez Velasco, 1992, entre otros). 
que cultural con el mundo greco-romano impuso una reelaboración de las bases sobre las que se sustentaba la identidad etnica de los grupos de habla indoeuropea del sur de la Península, o lo que es lo mismo, una aceleración del proceso de etnogénesis a través del cual las poblaciones herederas de las comunidades indígenas del Bronce Final reforzaban una vez más los vínculos de identidad y los lazos de solidaridad frente al "otro", que ya no era el púnico occidental o el cartaginés, sino una nueva cultura, con otra lengua, otras costumbres, que se había impuesto por la fuerza en toda la región (García Fernández, 2003: 197).

Los testimonios literarios son, en este contexto, una de las principales fuentes para hablar de una identidad turdetana, pero no como un grupo étnico pre- o protohistórico (aquí radica la diferencia), sino como el resultado natural de un proceso etnogenético que tiene su culminación durante las guerras de conquista y que termina con la plena incorporación -o mejor dicho, cambio de orientación- de las comunidades indígenas en la superestructura política y administrativa que representa el Imperio Romano.

A partir de este momento, la reintroducción de la escritura y la epigrafía -ya en latín- en el ámbito turdetano (Untermman, 1995), contemporáneamente a la aparición de nuevos elementos como la moneda, será aprovechada no sólo por los turdetanos, sino también por los púnicos, bastetanos, oretanos, etc. para expresar su identidad étnica y política. Baste recordar la inscripción hallada en los alrededores de Mérida dedicada a un personaje llamado L. Antonio Vegeto Túrdulo, que aún a finales del siglo I o principios del II tenía interés en destacar el étnico en su origo (Saquete, 1998); o la aparición de centuriaciones con nombres indígenas en algunas inscripciones del Bajo Guadalquivir (Sáez, 1978), que revelan la vigencia del substrato autóctono en el ámbito rural (Chic, 1999 y 2001). Esta pujanza del elemento indígena se refleja también en el mantenimiento de los sistemas de gobierno interno de numerosas comunidades políticas, "que se realizan al amparo de determinadas fórmulas institucionales romanas" (Sáez, 1994: 467).

Por último, uno de los testimonios más significativos es sin lugar a dudas la amonedación indígena, tanto en lo que se refiere a los tipos como a las leyendas. Aunque ha sido objeto de numerosos estudios (por ejemplo, Alfaro y otros, 1997), sólo en los últimos años se ha empezado a poner de relieve la importancia de la numismática para el conocimiento de las identidades étnicas y políticas de las ciudades turdetanas (Chaves, 1992, 1994 y 2000; Domínguez Monedero, 2000). Sin embargo, no debemos olvidar que se trata de documentos estrechamente ligados a la romanización, en un contexto histórico difícilmente extrapolable a momentos anteriores, aunque sin duda puede ofrecer algunas pistas sobre los vínculos identitarios que caracterizan a las comunidades prerromanas del Bajo Guadalquivir (Chic, 2000: 153, ver Chaves y otros, 2006).

\section{B) Los Púnicos}

El caso de las comunidades púnicas occidentales resulta menos confuso, al contar con testimonios materiales mucho más elocuentes; sin embargo, tampoco podemos dejarnos llevar por la impresión de homogeneidad -más aparente que real-que ofrecen los testimonios escritos y que ha sido asumida por una buena parte de la comunidad científica, ya que un análisis detallado de la documentación literaria y arqueológica, así como de sus contextos sociales revela, como veremos a continuación, una realidad mucho más diversa.

Durante las últimas décadas se viene aceptando que los colonizadores orientales llegados a la Península Ibérica no formaron un grupo homogéneo sino todo lo contrario (González y Alvar, 1989: 95), siendo su procedencia de lo más variopinta, independientemente de que el "proyecto" colonial (si es que lo hubo) respondiera a una iniciativa política de la metrópolis tiria. Blázquez, por ejemplo, ha puesto de manifiesto las concomitancias existentes entre los santuarios orientalizantes de El Acebuchal en Carmona o La Muela de Cástulo (Jaén) y los santuarios rurales documentados en Chipre (Blázquez y Valiente, 1981: 204-207), si bien los mosaicos de guijarros aparecidos en este último sugieren a su excavador la presencia de una comunidad siria del norte más que chipriota (Blázquez, 1986: 56). Lo mismo se puede decir del complejo de Montemolín (Marchena, Sevilla), donde las estructuras exhumadas cuentan con paralelos claros en la arquitectura palestina de finales de la Edad del Bronce y sobre todo de principios de la Edad del Hierro, momento en que se extiende por toda la región (Chaves y Bandera, 1991). Más llamativo es el caso de las cerámicas figurativas que aparecieron depositadas en su interior, cuyos prototipos más próximos se encuentran en Chipre y los yacimientos greco-orientales (Chaves y Bandera, 1986 y 1995). No olvidemos que ni en la costa sirio-palestina ni en las colonias fenicias occidentales, tanto de la Península Ibérica como del norte de África, se han documentado hasta la fecha cerámicas decoradas con motivos figurados, por lo que pudo tratarse de un fenómeno local, centrado en el valle del Guadalquivir, donde se asentaron gentes del Mediterráneo Oriental que conservaban aún la tradición de la cerámica figura- 
da, reinterpretada a partir de modelos antiguos en el contexto de una profunda hibridación con otras poblaciones de origen semita (Chaves y Bandera, 1995: 73 ss.).

Por lo que respecta a las necrópolis "orientales" del ámbito tartésico, la mezcla de tradiciones de origen sirio-palestino y chipriota, así como la incorporación de elementos procedentes de las sociedades indígenas, sobre todo en la composición de los ajuares, revela de forma meridiana la complejidad del fenómeno orientalizante, que no se puede explicar simplemente a través del choque entre indígenas y colonizadores como dos bloques culturales bien diferenciados, sino que abarca otros procesos de interacción (Belén y Escacena, 1995), e incluso de mestizaje (González y Alvar, 1989: 98), al menos al nivel de las elites, en los que participan grupos foráneos de distinta procedencia y un componente local muy heterogéneo. Según A.Mª Jiménez, "los comportamientos y las expresiones funerarias desarrolladas en Las Cumbres, Cruz del Negro, Filigrana, Boliche y, probablemente Mesas de Asta, Alcacer do Sal y Peña Negra", a la que podríamos añadir Cástulo (Bandera y Ferrer, 1995), son el reflejo de una sociedad "que ha incorporado formas culturales orientales e indígenas en una síntesis lo bastante coherente como para reproducirse en puntos distantes como Ibiza, probablemente desde el cercano asentamiento de La Fonteta" (Jiménez Flores, 2002: $188-189)^{15}$.

A pesar de ello, se admite generalmente la existencia de una identidad y una conciencia étnica de las comunidades semitas asentadas en el Occidente mediterráneo en relación con sus orígenes tirios. Según López Castro (2004: 150), "la particularidad de la etnicidad fenicia occidental, a diferencia de otras etnias de la Península Ibérica antigua, es que estaba en buena parte construida y consolidada, y se interrelacionaba estrechamente con estructuras sociales de clases y con estructuras políticas urbanas, de ciudades-estado orientales". Desde este punto de vista los fenicios occidentales no constituirían un "estado étnico", por así decirlo, como ocurría con Israel, sino "un conjunto de colonias dependientes de una ciudad-estado que compartían rasgos étnicos y que posteriormente se articularían como nuevas ciudades-estado legitimadas por sus orígenes" (ibidem). La etnicidad de estas comunidades se

\footnotetext{
${ }^{15}$ En el caso de estas comunidades, añade A.M ${ }^{\mathrm{a}}$. Jiménez, "los restos permiten avanzar el uso de una vestimenta diferente a la empleada por los grupos fenicios". En este sentido "el vestido, al igual que el adorno personal, constituye la expresión exterior más diáfana de un grupo cul-
}

sustentaría, por tanto, en tres pilares fundamentales, a saber: su origen, representado por el etnónimo can'ani o cananeos (López Castro, 1992: 344; Belmonte, 2003, con bibliografía), y más concretamente con la ascendencia tiria de la mayor parte de la población; la lengua, que se expresa a través del alfabeto púnico; y el culto a las divinidades oficiales del panteón fenicio (López Castro, 2004).

No obstante, si bien estos elementos tienen una clara operatividad a nivel político e ideológico, por cuanto constituyen un marco de identidad amplio que agrupa en principio a todas las comunidades de origen semita occidental, independientemente de su procedencia (siria, chipriota, libanesa, etc.), incluyendo las antiguas colonias fenicias de la Península Ibérica y norte de África, pensamos que en realidad enmascara una situación más compleja.

Desde que Tarradell acuñara el concepto de "círculo del Estrecho" (Tarradell, 1960: 61) una parte de la investigación se ha decantado por la existencia de una "unidad cultural y económica semita extremo occidental" diferente a la cartaginesa (Niveau, 2001: 320). En este contexto, la ecuación origen-lenguacultos podría haber desempeñado un papel clave en el deseo de Gadir por distanciarse de la hegemonía de Cartago, recurriendo a sus viejos vínculos con Tiro. Pero no hay que olvidar que Cartago también es una fundación tiria y, como tal, comparte sus orígenes y en gran medida también su lengua, cultos y costumbres con la metrópolis oriental, independientemente de que su conciencia de identidad se estuviera reorientando hacia nuevas formas de integración. Cartago es tan fenicia -y en cierto sentido tan tiria- como la propia Cádiz; prueba de ello es que, aunque su población desencadena un proceso etnogenético que deriva en lo que usualmente denominamos "púnicos de Cartago" o "cartagineses", sabemos por la literatura antigua que la "nueva ciudad" enviaba cada año una embajada a celebrar un sacrificio al templo de Melkart en Tiro (Quinto Curcio, IV.2.10; Diod., XX.14; Plb., XXXI.12), así como frecuentes ofrendas y botines en señal de fidelidad a la antigua metrópolis (Lancel, 1994: 67). En el fondo de todo se encontraría, por tanto, el interés de las elites ciudadanas por definir sus respectivas esferas de identidad con respecto a las demás: Cádiz recurriendo a sus orígenes tirios, Cartago a una nueva realidad, más política que étnica, que tiene su

tural. Es plausible argumentar que cada grupo cultural activa estas formas expresivas en el momento del sepelio, como signo constituyente de la persona social del difunto" (Jiménez Flores, 2002: 189-190). 
máxima expresión en la propia constitución ciudadana, en los cultos estatales y en los rituales funerarios (Plácido y otros, 1991: 103 y ss.).

Por otra parte, no creemos que todos los fenicios occidentales participaran de la misma ecuación origen(tirio)-lengua-cultos, al menos no en la misma medida que los gaditanos. De hecho, no se puede esperar que de un sustrato tan heterogéneo como el que se materializa durante la colonización fenicia arcaica (vide supra) devenga una identidad púnica occidental compacta y monolítica (Ferrer, 2004), ajena a los procesos sociales y mentales que desencadena la desvinculación con Tiro, así como las coyunturas históricas que a escala regional afectan a las antiguas ciudades fenicias del Mediterráneo Occidental. La presencia púnica en el interior de la Turdetania y su interacción con el componente local debió generar necesariamente procesos de integración y/o diferenciación que aún no han sido suficientemente valorados, pero que han dejado huellas evidentes no sólo en el registro material, sino también en la organización sociopolítica y en la explotación económica del territorio (García Moreno, 1992). A ello habría que unir la intervención de Cartago, cada vez más intensa a medida que avanzamos durante los siglos IV y III a.C. (Koch, 2001), como se desprende de la aparición de tesorillos con monedas sículo-púnicas y cartaginesas en la Campiña de Sevilla (Pliego, 2003).

En este sentido, los testimonios literarios, así como la documentación numismática y epigráfica de época romana, demuestran que dentro de este “espacio cultural púnico” definido por Ferrer (1998) se encuentran representados diferentes niveles de integración sociopolítica y étnica. Por un lado tenemos las ciudades fenicias de la costa, sucesoras de las antiguas factorías de época colonial y con una población mayoritariamente semita (López Castro, 2003). Estas poleis -como las define Hecateogozaron de una gran autonomía, como puede desprenderse de las acuñaciones de época romana, cuyos tipos y leyendas reflejan claramente el interés de sus ciudadanos por diferenciarse de los demás (Domínguez Monedero, 2000: 60-61), ya sea a través de imágenes y símbolos, ya sea bajo el uso de fórmulas del tipo $M B^{\prime} L$ junto al topónimo, que viene a indicar su procedencia "de los ciudadanos de..." (Alfaro, 1991). Desde el punto de vista político y comercial las comunidades fenicias occidentales pueden agruparse en dos áreas de influencia bien diferenciadas: el "círculo del Estrecho", con Cádiz a la cabeza, que extiende su radio de acción a lo largo del litoral atlántico hasta el Guadiana (Chaves y García, 1991); y las ciudades "mastienas" -Seks, Malaka, Abdera, entre otras- situadas en la costa
Mediterránea, al este de las Columnas de Heracles (Ferrer y Prados, 2002). Sin embargo, desde mediados del siglo IV a.C. ambos territorios acaban entrando a formar parte de la órbita de Cartago, bien a través de alianzas desiguales (López Castro, 1991a y 1991b), o más probablemente mediante la formalización de ligas orientadas hacia la defensa de intereses comunes (Arteaga, 1994).

Por otro lado nos encontramos una serie de comunidades que podríamos denominar "mixtas", en las que el componente semita no es mayoritario pero sí predominante, ya que determinan en buena medida la vinculación política y comercial de la población hacia las poleis costeras. Nos estamos refiriendo a Ituci y Olontigi, ciudades que a pesar de encontrarse situadas en el interior del antiguo estuario del Guadalquivir, es decir, en territorio de los turdetanos -por así decirlo-, amonedan en época romana con la leyenda en alfabeto púnico (Alfaro, 1991). Especial atención merecen las cecas que se conocen convencionalmente como "libiofenicias": Asido, Lascuta, Iptuci, Turirrecina, entre otras (García y Bellido, 1985-86 y 1993). En este caso nos encontraríamos ante "una serie de comunidades de procedencia oriental que se constatan en el interior ya durante la época de la colonización fenicia (...) y que debieron evolucionar junto a los habitantes indígenas de la zona" (Chaves, 2000: 114); o bien, como matiza Ferrer (2000: 430), se trataría de "comunidades púnicas o muy punicizadas, de antigua tradición semita, o con vínculos estrechos con ciudades púnicas como Gadir" que debido a su aislamiento, y sobre todo a la fuerte influencia latina, consecuencia de la descentralización lingüística surgida tras la destrucción de Cartago, emiten sus monedas con caracteres aberrantes, dando lugar a distintas formas de escritura neopúnica (Solá-Solé, 1980).

Para terminar, es preciso destacar la presencia púnica en ciudades claramente turdetanas, como Carmo o Urso, y en otras menos claras, como Hispalis o Asta Regia, donde las evidencias literarias y arqueológicas no dejan lugar a dudas de la existencia de comunidades semitas más o menos establecidas cohabitando con el componente étnico local, o bien de antiguos emporios comerciales (Escacena, 2004) en los que la intensa interacción entre indígenas y colonizadores ha podido dar lugar a fenómenos puntuales de hibridación o mestizaje cultural. De nuevo cabe hacer referencia al testimonio transmitido por Estrabón (III.2.13), quién afirmaba que la región llegó a estar tan completamente sometida a los fenicios, que la mayor parte de las ciudades de la Turdetania y de los lugares cercanos estaban todavía habitados por aquéllos. Es el caso de Carmo, cuya necrópolis neopúnica confirma la 
existencia de una población semita estable que todavía mantenía sus ritos y costumbres durante los primeros siglos de la presencia romana (Bendala, 1976 y 1982). Este fenómeno puede ponerse también en relación con la pervivencia de cultos betílicos, documentados en diversos lugares de la Turdetania, como Marchena (Bandera y otros, 2004), Carmona (Belén y otros, 1997 y 2001) o Torreparedones (Seco, 1999). Por lo que se refiere a Sevilla, recientes estudios están poniendo de manifiesto su proximidad al "círculo del Estrecho", al menos desde el punto de vista comercial, como se deduce de la abundancia de ánforas de producción púnico-gaditana, así como de la aparición de determinadas formas de la vajilla común que se aproximan al repertorio de tradición fenicia evolucionada producido en los talleres del entorno de Gadir $^{16}$. Lo mismo se puede decir del poblado y la necrópolis de Asta Regia, donde la presencia mayoritaria de ánforas púnicas del Estrecho y de cerámicas de mesa típicamente gaditanas (González y otros, 1997) -en las que se integra la vajilla de lujo "tipo Kouass" (Niveau, 2000)-, unido a la aparición de una estela púnica en forma de ara (Esteve, 1950), puede demostrar, frente a la opinión de Chic García (1994), un predominio del componente púnico sobre el tartésico-turdetano (García Fernández, 2003b).

Una vez más la numismática de época romana resulta bastante elocuente en este sentido, por cuanto se observa en la mayor parte de las cecas conocidas como "turdetanas" la aparición junto a los rótulos latinos de elementos procedentes del mundo púnico -como el creciente (Orippo, Ilippa), el caballo parado con pata alzada (Sacili, Nabrissa), etc. (García y Bellido, 1990, entre otros)- y, sobre todo, de "tipos propios que pueden haber estado inspirados, más o menos lejanamente, por los existentes en las acuñaciones fenicio-púnicas, aunque reinterpretados localmente" (Domínguez Monedero, 2000: 64). Un caso singular es el de las monedas de Urso, cuyas series de mayor valor presentan en ocasiones junto a la leyenda en latín el signo fenicio yod, interpretado como una marca de valor (Villaronga, 197980: 244-245). Todo ello no es más que un reflejo de la problemática que encierran estas comunidades ciudadanas, mayoritariamente turdetanas pero estrechamente ligadas en determinados aspectos a la tradición púnica; situación ésta que les permitirá matizar, de manera más o menos instrumentalizada, su

\footnotetext{
${ }^{16}$ Se encuentra en preparación un trabajo llevado a cabo por E. Ferrer Albelda, D. González Acuña y el propio autor en el que se analizan diferentes contextos de consumo procedentes de excavaciones arqueológicas realizadas en la ciudad de Sevilla, donde se puede apreciar la
}

identidad política y probablemente también étnica en favor del substrato fenicio, con el que habían convivido durante siglos, sirviendo también como fórmula para el establecimiento de pactos y alianzas con los nuevos adstratos, encabezados por la propia Gadir, que aún sabrá mantener su pujanza a nivel económico y cultural durante los primeros siglos de la presencia romana (Chaves y García, 1991; Chaves, 2000).

Así pues, bajo el apelativo generalizador de púnicos o fenicios occidentales se esconden en realidad diversas identidades vinculadas en mayor o menor medida por un origen, una lengua, unas creencias o unas costumbres comunes, y cuya integración en los contextos coloniales permite distinguir matices a escala local e incluso fenómenos de hibridación o diferenciación que dan lugar a nuevos procesos identitarios, ya sea a nivel político como étnico. Del mismo modo que el término "helene" era conscientemente utilizado por los griegos para diferenciarse de "los otros" - los bárbaros(Prontera, 1999: 149), agrupando diferentes grupos étnicos unidos por "la consanguinidad y la comunidad de lengua, de creencias religiosas, de ritos sacrificiales, de usos y de costumbres" (Hdt. VIII, 144), el término "can'ani" debió constituir un nivel de agrupación étnica superior que abarcaría a la mayor parte de las poblaciones de raíz semita que participaron en la experiencia colonial, sin perjuicio de que entre ellos existieran otros niveles de diferenciación. Es más, se trata de conceptos dinámicos que pueden ir adquiriendo un carácter más amplio o restrictivo a lo largo del tiempo. De todos es conocido que los griegos centrales y meridionales pusieron en duda frecuentemente la "helenidad" de los pueblos septentrionales, entre los que se encontraban los macedonios, tesalios, ambraciotas, etc. (Cardete, 2004: 20-21), en base a matices variables que podían pasar desapercibidos en otras ocasiones. En este sentido, conviene recordar la referencia de San Agustín (Epist. ad Rom. Inch. Exp. 13), quién afirmaba ya en el siglo V de nuestra Era que las poblaciones campesinas del norte de África hablaban todavía la lengua cartaginesa y se hacían llamar a sí mismas chanani.

\section{CONCLUSIÓN: ETNIAS, TERRITORIOS Y FRONTERAS}

Todo lo visto hasta ahora permite concluir que las fronteras étnicas entre las poblaciones de la

proximidad de los repertorios cerámicos correspondientes a los siglos IV y III a.C. con los documentados en las factorías costeras del entorno de Cádiz, como el poblado de Las Cumbres o el Castillo de Dña. Blanca (Ferrer y otros, e.p.). 
Turdetania son dinámicas y extremadamente permeables, si es que se puede hablar de fronteras en unos contextos geo-etnográficos tan sumamente complejos como los que se desarrollan en el sur de la Península Ibérica en época prerromana. El concepto de frontera, tal como hoy se entiende, tiene un carácter más político que cultural y se encuentra inescrutablemente unido a la noción de estado (Castro y González, 1989), como modelo de organización socio-política que es capaz de asegurar y mantener a una población estable sobre un territorio determinado, dentro de unos límites establecidos que pueden variar en el tiempo, en virtud de su interacción con otras formaciones estatales vecinas. En consecuencia, "la noción de espacio de transición entre los territorios de dos sociedades, no contiene unívocamente el concepto de frontera. Sociedades cuya apropiación del territorio no se basa en su delimitación y en su defensa (...), sino en su utilización, pueden poseer los recursos de un espacio geográfico determinado, y asumir como propio éste, a partir de representaciones que contengan la noción de $l o$ que no es". Por el contrario, "el espacio en el cual las instituciones de un estado dejan de ejercer con efectividad su poder, bien ante la presencia de otro estado, bien ante grupos sociales en los cuales no está asegurada la reproducción de las relaciones sociales dominantes (...) constituye la frontera" (Castro y González, 1989: 11 y 15).

Así pues, cuando se trata de niveles de identidad étnica y no de identidades políticas, más que de fronteras físicas habría que hablar de "límites" territoriales, o mejor aún, de fronteras sociales; ya que, ¿es posible realmente definir territorios exclusivos para los diferentes grupos étnicos en una región como la Turdetania, donde comunidades con un origen diverso han compartido durante siglos los mismos nichos ecológicos y han convivido de manera más o menos pacífica -dependiendo de las circunstancias concretas- en los mismos núcleos de población? Hay que partir de la base de que el territorio no debe entenderse unívocamente como una superficie tridimensional, sino un espacio semiotizado en el que pueden interrelacionarse diversos grupos étnicos. Es lo que J. Cabezas califica como "campos étnicos", "asimilables a una suerte de campos simbólicos alrededor de los cuales pivotarían los sistemas sociales" (Cabezas, 2003). En este sentido los límites étnicos o las "fronteras sociales" no serían barreras físicas infranqueables entre grupos culturales uniformes, sino canales de comunicación que facilitan la interacción y estimulan la mutua reelaboración de las identidades colectivas. De hecho, "numerosos núcleos etnogenéticos (...) se hallan (o surgen) en zonas de frontera, es decir, en áreas de densa comunicación, de 'contactos' interétnicos que facilitan la toma de conciencia de una especificidad que se torna diferencia y que concluye (nunca de manera definitiva) en un proceso de fronterización hacia el exterior y de galvanización endógena" (ibidem).

Una vez visto esto podríamos redefinir la pregunta, ¿es posible identificar espacialmente a las antiguas etnias de la Turdetania? En cierto sentido sí, aunque no como bloques territoriales monolíticos, sino más bien como "áreas de predominio" en las que se apreciaría con mayor intensidad la presencia mayoritaria o predominio de un determinado grupo étnico sobre los demás; sin olvidar que existen casos en los que pueden convivir varios grupos sin que se advierta la superioridad de alguno en particular. Para ser más precisos habría que subrayar en cada contexto el tipo de presencia o el nivel de predominio, demográfico, político (dominio, coerción militar, etc.), económico o cultural: control de las elites mediante el establecimiento de relaciones de prestigio, introducción de instrumentos de cohesión, como cultos o festividades, procesos de mestizaje, etc. La escala a la que se puede observar este fenómeno también es variable, desde un núcleo protourbano como puede ser Carmona, hasta un territorio más o menos amplio como la antigua desembocadura del Guadalquivir, donde se distinguen comunidades púnicas y de tradición turdetana, algunas de ellas intensamente punicizadas. Lo mismo podemos decir de la Beturia, que se acaba convirtiendo en un frente donde confluye el antiguo substrato tartésicoturdetano, las comunidades célticas infiltradas desde la meseta y algunos grupos aislados de población fenicio-púnica que han pervivido desde época colonial a expensas de su papel como intermediarios en las vías de comunicación que se dirigen hacia norte y oeste de la Península.

En conclusión, el mapa paleoetnológico de la Turdetania no se compone de áreas culturales o etnolingüísticas delimitadas por fronteras estables en el espacio y en el tiempo. No se trata de blanco o negro, sino de una amplia gama matices cromáticos que se difuminan, solapan, yuxtaponen, mezclan y asimilan, dando lugar en ocasiones a nuevas realidades, en función del contexto geohistórico y social en el converjan las diferentes identidades.

A falta de un análisis más exhaustivo que tenga en cuenta otras poblaciones presentes en la Turdetania, como los "celtas", lusitanos, bastetanos u oretanos, así como otras variables y expresiones de la identidad en sus diferentes escalas (étnica, política y social, etc.), sirva esta reflexión para incidir sobre la dimensión de un fenómeno cuya com- 
plejidad (en ocasiones ignorada) supera con creces las expectativas de la investigación. Nos conformaremos, por ahora, con echar más leña al fuego de la incertidumbre que, por principio, caracteriza al comportamiento humano.

Sevilla, 30 de Marzo de 2005

\section{Bibliografía}

ALFARO ASINS, C. (1991): "Epigrafía monetal púnica y neopúnica en Hispania. Ensayo de síntesis", en Ermanno E. Arslan Studia Dicata (Glaux 7), Milán: 109-150.

ALFARO ASINS, C. y otros (1997): Historia monetaria de Hispania antigua, Madrid.

ALMAGRO GORBEA, M. (1982): “Tumbas de cámara y cajas funerarias ibéricas. Su interpretación socio-cultural y la delimitación del área cultural ibérica de los bastetanos", en Homenaje a Conchita Fernández Chicarro, Madrid: 249-258.

ALMAGRO GORBEA, M. y RUIZ ZAPATERO, G. (eds.) (1992): Paleoetnología de la Península Ibérica (Complutum 2-3), Madrid.

ARTEAGA MATUTE, O. (1994): “La liga púnica gaditana. Aproximación a una visión histórica occidental, para su contrastación con el desarrollo de la hegemonía cartaginesa, en el mundo mediterráneo", en Cartago, Gadir, Ebusus y la influencia púnica en los territorios hispanos (VIII Jornadas de Arqueología Fenicio-Púnica), Ibiza: 25-57.

BAILLI, A. (1950): Dictionnaire Grec-Français, París.

BANDERA, M ${ }^{\mathrm{a}}$.L. y FERRER, E. (1995): "Reconstrucción del ajuar de una tumba de Cástulo: ¿indicios de mestizaje?", en Homenaje a F. Gascó (Kolaios 4), Sevilla: 53-65.

BANDERA, Mª.L. y otros (1993): "Montemolín. Evolución del asentamiento durante el Bronce Final y el Período Orientalizante (campañas de 1980 y 1981)", AAC 4: 15-47.

-----(2004): "Nuevas evidencias de cultos betílicos en Turdetania", en III Congreso Español de Antiguo Oriente Próximo (Huelva Arqueológica 20), Huelva: 241-255.

BARBER, E.J.W. (1999): "Colour in Early Cloth and Clothing”, CAJ 9-1: 117-120.

BARTH, F. (1976): "Introducción", en F. Barth (coord.), Los grupos étnicos y sus fronteras. La organización social de las diferencias culturales, México (1 ${ }^{\mathrm{a}}$ ed. Londres, 1969): 9-49.

BATS, M. (2002): "Du cratère sympotique au stam- mos funéraire: tombes à armes du Midi de la Gaule (IVe-Ier siècles av. J.-C.)", en Christel Müller y Francis Prost (eds.), Identités et cultures dans le monde méditerranéen antique, París: 277302.

BELÉN DEAMOS, M. (1976): "Estudio y tipología de la cerámica gris de Huelva”, RABM LXXIX (2): 353-388.

BELÉN, M. y ESCACENA J.L. (1991): “El mundo funerario del Bronce Final en la fachada atlántica de la Península Ibérica. I. Análisis de la documentación", TP 48: 225-256.

-----(1995): "Interacción cultural fenicios-indígenas en el Bajo Guadalquivir", en Homenaje a F. Gascó (Kolaios 4), Sevilla: 67-101.

----(1997): “Testimonios religiosos de la presencia fenicia en Andalucía Occidental”, Spal 6: 103131.

BELÉN, M. y otros (1997): Arqueología en Carmona (Sevilla). Excavaciones en la casa-palacio del Marqués de Saltillo, Sevilla.

----(2001): “Cultos betílicos en la Carmona romana”, en Antigüedad: Religiones y Sociedad (ARYS 4), Huelva: 141-164.

BELMONTE MARÍN, J.A. (2003): Cuatro estudios sobre los dominios territoriales de las ciudadesestado fenicias, Barcelona.

BELTRÁN LLORIS, F. (1986): “Un espejismo historiográfico. Las organizaciones gentilicias hispanas", en Actas del I Congreso Peninsular de Historia Antigua, Santiago de Compostela: 197237.

BENDALA GALÁN, M. (1976): La necrópolis romana de Carmona (Sevilla), Sevilla.

-----(1981): "La etapa final de la cultura ibero-turdetana y el impacto romanizador", en La baja época de la cultura ibérica, Madrid: 33-48.

-----(1982): “La perduración púnica en los tiempos romanos: el caso de Carmo", Huelva Arqueológica VI: 193-203.

-----(2000): Tartesios, iberos y celtas, Madrid.

BENTLEY, G.C. (1987): "Ethnicity and Practice", Comparative Studies in Society and History 29 (1): 24-55.

BLÁZQUEZ MARTÍNEZ, J.Ma . (1986): “La colonización fenicia en la Alta Andalucía (Oretania). S. VIII-VI a.C.", RSF XIV (1): 53-80.

BLÁZQUEZ, J. Mª y VALIENTE, J. (1981): Cástulo 


\section{III (EAE 117), Madrid.}

BOHR, N. (1988): La teoría atómica y la descripción de la naturaleza, Madrid.

BOSCH GIMPERA, P. (1932): Etnología de la Península Ibérica, Barcelona.

BURILLO MOZOTA, F. (1997): "Espacios cultuales y relaciones étnicas: contribución a su estudio en el ámbito turolense durante época ibérica", en Espacios y lugares cultuales en el mundo ibérico (Quaderns de Prehistòria i Arqueologia de Castelló 18): 229-238.

----(1998): Los celtíberos: etnias y estados, Barcelona.

CABEZAS LÓPEZ, J.M. (2003): "Frontera, territorio e identidad: los etnosistemas", Nómadas 8: Publicaciones Electrónicas. Universidad Complutense de Madrid (ISSN 1578-6730Depósito Legal: M-49272-2000).

CAMPBELL, A. (1997): "Ethical Ethnicity: a Critique", The Journal of Modern African Studies 35 (1): 53-79.

CARDETE DEL OLMO, Ma .C. (2004): “Ethnos y etnicidad en la Grecia clásica", en G. Cruz Andreotti y B. Mora Serrano (coords.), Identidades étnicas - Identidades políticas en el mundo prerromano hispano, Málaga: 15-29.

CARRIAZO, J. DE MATA (1973): Tartessos y El Carambolo, Madrid.

CASTRO MARTÍNEZ, P.V. y GONZÁLEZ MARCÉN, P. (1989): "El concepto de frontera: Implicaciones teóricas de la noción de territorio político", Fronteras. Arqueología Espacial 13: 718.

CHAPA BRUNET, T. y PEREIRA SIESO, J. (1994): "Las etnias prerromanas del Sureste: problemas de su comprobación arqueológica", en II Congreso de Historia de Andalucía, Córdoba: 89105.

CHAVES TRISTÁN, F. (1992): “Moneda y ciudad en el Sur de la Península Ibérica", en L'Africa Romana, Atti del X Convegno di Studi, Sassari: 1305-1318.

-----(1994): "Indigenismo y romanización desde la óptica de las amonedaciones hispanas de la Ulterior", Habis 25: 107-120.

-----(2000): “¿La monetización de la Bética desde las colonias púnicas?”, en Mª.P. García-Bellido y L. Callegarin (coords.), Los cartagineses y la monetización del Mediterráneo Occidental (Anejos de
AEspA XXII), Madrid: 113-126.

CHAVES, F. y BANDERA, M ${ }^{\mathrm{a}}$.L. de la (1986): "Figürlich verzierte Keramik aus dem Guadalquivir-Gebiet", MM 27: 117-150.

----(1991): “Aspectos de la urbanística en Andalucía Occidental en los S. VII-VI a.C. a la luz del yacimiento de Montemolín (Marchena, Sevilla)", en Atti del II Congresso Internazionale di Studi Fenici e Punici, Roma: 691-714.

-----(1995): "Problemática de las cerámicas orientalizantes y su contexto", en Lengua y cultura en la Hispania prerromana. Actas del $V$ Coloquio sobre Lenguas y Culturas Prerromanas de la Península Ibérica, Salamanca: 49-89.

CHAVES, F. y GARCÍA, E. (1991): "Reflexiones en torno al área comercial de Gades: estudio numismático y económico", en Alimenta. Homenaje al Prof. M. Ponsich (Anejos de Gerión), Madrid: 139-168.

CHAVES, F. y otros (2006): "Relaciones interétnicas e identidades culturales en la Turdetania (siglos II a.C.-II d.C.)", en L'Africa Romana, XVI Convegno di Studi, Roma: 813-828.

CHIC GARCÍA, G. (1994): "Lucubraciones en torno al Conventus de Hasta (Estrabón III ,2,2.141)", en Homenaje al Profesor Presedo, Sevilla: 391-402.

-----(1998): “La transformación de los sistemas de convivencia: hacia la formación de las urbes en el sur de Hispania", en Italia e Hispania en la Crisis de la República. Actas del III Congreso HispanoItaliano, Madrid: 295-306.

-----(2000): "La romanización de las ciudades púnicas: la aportación de la numismática", en $\mathrm{M}^{\mathrm{a}}$.P. García-Bellido y L. Callegarin (coords.), Los cartagineses y la monetización del Mediterráneo Occidental (Anejos de AEspA XXII), Madrid: 145-156.

----(2001): "Religión, territorio y economía en la Carmo romana", Actas del II Congres de Historia de Carmona. Carmona Romana, Carmona: 287-297.

CIPRÉS, P. (1993): “Celtiberia: la creación geográfica de un espacio provincial”, Ktema 18: 259-291.

CRUZ ANDREOTTI, G. (1996): "Romanización y paisaje en la Geografía Antigua. El ejemplo hispano", en A cidade e o mundo: romanización e cambio social, Xinzo de Limia: 53-64.

-----(2002): "Iberia e iberos en las fuentes históricogeográficas griegas: una propuesta de análisis", Mainake XXIV (número monográfico): 153-180. 
DÍAZ-ANDREU, M. (1995): “Archaeology and Nationalism in Spain”, en P.L. Kohl y C. Fawcett (eds.), Nationalism, Politics and the Practice of Archaeology, Cambridge: 39-56.

DÍAZ SANTANA, B. (2003): "Los celtas. Identidad, etnicidad y arqueología”, Spal 12: 299-316.

DÍEZ VELASCO, F. (1992): "Divinités des eaux thermales dans le Nord-Ouest de la prouincia Tarraconensis et dans le Nord de la prouincia Lusitania: une approche au phénomène du thermanlisme romain dans l'occident des Provinces Ibériques", en Les eaux thermales et les cultes de eaux en Gaule et dans les provinces voisines (Caesarodunum 26): 133-149.

DIHLE, A. (1990): "Etnografía ellenistica", en F. Frontera(ed.), Geografia e geografi nel mondo antico, Roma-Bari: 173-199.

DOMÍNGUEZ MONEDERO, A.J. (1983): "Los términos Iberia e Iberos en las fuentes grecolatinas: estudio acerca de su origen y ámbito de aplicación”, Lucentum II: 203-224.

-----(1997): "Los lugares de culto en el mundo ibérico: espacio religioso y sociedad", en Espacios y lugares cultuales en el mundo ibérico (Quaderns de Prehistòria i Arqueologia de Castelló 18): 391404.

-----(2000): "Monedas e identidad étnico-cultural de las ciudades de la Bética", en $\mathrm{M}^{\mathrm{a}}$.P. GarcíaBellido y L. Callegarin (coords.), Los cartagineses y la monetización del Mediterráneo Occidental (Anejos de AEspA XXII), Madrid: 59-74.

DOWNS, M.E. (1998): "Turdetani and Bastetani: Cultural Identity in Iberian and Early Roman Baetica", en S. Keay (ed.), The Archaeology of Early Roman Baetica, Portsmouth: 39-53.

EICHER, J.B. (1995): Dress and Ethnicity: Change across Space and Time, Oxford.

ERIKSEN, T.H. (1993): Ethnicity and Nationalism. Anthropological Perspectives, Londres.

ESCACENA CARRASCO, J.L. (1987): “El poblamiento ibérico en el Bajo Guadalquivir", en Iberos. Actas de las Primeras Jornadas sobre Mundo Ibérico, Jaén: 273-297.

-----(1987b): Cerámicas a torno pintadas andaluzas de la segunda edad del hierro (Tesis Doctoral microfilmada), Cádiz.

-----(1989): "Los turdetanos o la recuperación de la identidad perdida", en $\mathrm{M}^{\mathrm{a}}$.E. Aubet (coord.), Tartessos. Arqueología Protohistórica del Bajo Guadalquivir, Sabadell: 433-476.
-----(1992): "Indicadores étnicos en la Andalucía prerromana”, Spal 1: 321-343.

-----(2004): “Tartessos (des)orientado”, Colonialismo e interacción cultural: el impacto fenicio púnico en las sociedades autóctonas de Occidente (XVIII Jornadas de Arqueología Fenicio-Púnica), Ibiza: 7-55.

ESCACENA, J.L. y BELÉN, M. (1994): "Sobre las necrópolis turdetanas", en Homenaje al Profesor Presedo, Sevilla: 237-265.

ESTEVE GUERRERO, M. (1950): "Excavaciones en Asta Regia (Mesas de Asta, Jerez). Campaña de 1945-46”, Informes y Memorias 22, Madrid.

FERRER ALBELDA, E. (1998): "Suplemento al mapa paleoetnológico de la Península Ibérica: los púnicos de Iberia”, RSF XXVI (1): 31-54.

----(2000): "Nam sunt feroces hoc libyphoenices loco: ¿libiofenicios en Iberia?, en Homenaje al Profesor Vallespí (Spal 9): 421-433.

-----(2004): "Sustratos fenicios y adstratos púnicos: los bástulos entre el Guadiana y el Guadalquivir," en III Congreso Español de Antiguo Oriente Próximo (Huelva Arqueológica 20), Huelva: 281298.

FERRER, E. y BANDERA, M ${ }^{\mathrm{a}}$.L. de la (2005): “El orto de Tartesos: la colonización agraria durante el periodo orientalizante", en Actas del Congreso de Protohistoria del Mediterráneo Occidental. El Periodo Orientalizante (Anejos de AEspA XXXV), Madrid: 565-574.

FERRER, E. y GARCÍA, F.J. (2002): “Turdetania y turdetanos: contribución a una problemática historiográfica y arqueológica", Mainake XXIV (número monográfico): 133-151.

FERRER, E. y PRADOS, E. (2001-2002): “Bastetanos y bástulo-púnicos. Sobre la complejidad étnica del sureste de Iberia", en Studia E. Cuadrado (AnMurcia 16-17), Murcia: 273-282.

FERRER, E. y otros (e.p.): "El comercio púnico en Spal”, VI Congreso Internacional de estudios Fenício Punicos (Lisboa 2005).

FRUTOS REYES, G. de (1991): Cartago y la política colonial: los casos norteafricano e hispano, Écija (Sevilla).

GAGE, J. (1999): "Did colours signify? Simbolism in the Red", CAJ 9 (1): 110-112.

GARCÍA-BELLIDO, A. (1963): "Los pueblos ibéricos”, en Historia de España Espasa-Calpe, I (3), Madrid: 373-666. 
GARCÍA-BELLIDO, Mª.P. (1985-1986): “Leyendas e imágenes púnicas en las monedas "Libyofenices", en IV Coloquio sobre Lenguas y Culturas Paleohispánicas (Veleia 2-3), Vitoria: 499-519.

----(1990): “Iconografía fenicio-púnica en la moneda romana republicana de la Bética", Zephyrus XLIII: 371-383.

-----(1993): “Las cecas libiofenicias”, en Numismática hispano-púnica. Estado actual de la investigación (VII Jornadas de Arqueología FenicioPúnica), Ibiza: 97-146.

GARCÍA FERNÁNDEZ, F.J. (2002): “Turdetania, turdetanos y cultura turdetana", Quaderni Ticinesi di Numismatica e Antichità Classiche XXXI: 191202.

-----(2002b): "Los turdetanos en la historiografía reciente: 25 años de avances y desencuentros", en Homenaje al Profesor Pellicer, II (Spal 11), Sevilla: 219-231.

----(2003): Los turdetanos en la Historia: análisis de los testimonios literarios grecolatinos, Écija (Sevilla).

----(2003b): El poblamiento turdetano en el Bajo Guadalquivir (Tesis Doctoral inédita). Universidad de Sevilla.

GARCÍA MORENO, L.A. (1989): “La Hispania anterior a nuestra Era: verdad, ficción y prejuicio en la historiografía antigua y moderna", en VII Congreso Español de Estudios Clásicos, III, Madrid: 17-43.

GARCÍA MORENO, L.A. (1988): “Hispaniae tumultus. Rebelión y violencia indígena en la España romana de época republicana", Polis 1: 81-107.

-----(1992): "Las ciudades béticas de extirpe púnica (un ensayo postmarxista)", Dialoghi d'Archeologia 1-2: 119-127.

GARCÍA QUINTELA, M.V. (1991): “Sources pour l'Étude de la protohistoire d'Hispanie. Pour une nouvelle lecture", DHA 17.1: 61-99.

GASANA, J.K. (1997): "La región de los Grandes Lagos, ¿África, tierra de conflictos?”, Inshuti [http://www.inshuti.org/gasana2.htm\#N2].

GENIÈRE, J. de la (1987): "Des usages du cratère", en P. Rouillard y M.-C. Villanueva-Puig (coords.), Grecs et Ibères au IVe siècle av. J.-C. (REA 89), Burdeos: 271-282.

GÓMEZ FRAILE, J.M. (1997): “Celtiberia y las fuentes grecolatinas. Replanteamiento conceptual de un paradigma obsoleto", Polis 8: 143-206.

----(1999): “Los conceptos "Iberia" e “ibero" en Estrabón”, Spal 8: 159-187.

-----(2001): "Reflexiones críticas en torno al antiguo ordenamiento étnico de la Península Ibérica", Polis 13: 69-98.

GONZÁLEZ MORALES, M.R. (1992): “Racines: la justification archéologique des origenes regionales dans l'Espagne des Communantés autonomes", en T. Shay y J. Clottes (eds.), The Limitations of Archaeological Knowledge, Lieja: 15-27.

GONZÁLEZ PONCE, F.J. (1995): Avieno y el periplo, Ecija (Sevilla).

GONZÁLEZ RODRÍGUEZ, R. y otros (1997): "Notas sobre el mundo funerario en la Baja Andalucía durante el periodo turdetano", en La Andalucía Ibero-Turdetana (Siglos VI-IV a.C.), (Huelva Arqueológica XIV), Huelva: 245-268.

GONZÁLEZ RUIBAL, A. (2003): La experiencia del Otro. Una introducción a la Etnoarqueología, Madrid.

GONZÁLEZ WAGNER, C. (1994): "El auge de Cartago (S. VI-V) y su manifestación en la Península Ibérica”, en Cartago, Gadir, Ebusus y la influencia púnica en los territorios hispanos (VIII Jornadas de Arqueología Fenicio-Púnica), Ibiza: 7-24.

GONZÁLEZ, C. y ALVAR, J. (1989): “Fenicios en Occidente: la colonización agrícola", $R S F$ XVII (1): 61-102.

GORROCHATEGUI, J. (1993): "Las lenguas de los pueblos paleohispánicos", en M. Almagro Gorbea y G. Ruiz Zapatero (coords.), Los celtas: Hispania y Europa, Madrid: 409-429.

GOSSELAIN, O.P. (2000): "Materializing identities. An African perspective", Journal of Archaeological Method and Theory 7 (3): 187-217.

GRILLI, A. (1979): “L'approccio all'etnología nell'antichità", en M. Sordi (ed.), Conoscenza etniche e rapporti di convivenza nell'antichità. CISA 6, Milán: 11-33.

HABA, S. y RODRIGO, V. (1990): "El tema del culto a las aguas y su continuidad en relación con las vías naturales de comunicación", Zephyrus XLIII: 271-279.

HALL, J. (1997): Etnic Identity in Greek Antiquity, Cambridge.

-----(1998): "Discourse and Praxis: Ethnicity and Culture in Ancient Greece", CAJ 8 (2): 266-269. 
HARRIS, M. (1990): Antropología cultural, Madrid.

HAWKING, S. (1993): Historia del tiempo. Del Big Bang a los agujeros negros, Barcelona.

HERNANDO GONZALO, A. (1995): "La Etnoarqueología, hoy: una vía eficaz de aproximación al pasado", TP 52 (2): 15-30.

HODDER, I. (1988): Interpretación en Arqueología. Corrientes actuales, Barcelona.

INIESTA SANMARTÍN, A. (1989): "Notas para la reconstrucción del área mastieno-bastetana en el sureste peninsular", en XIX CNA, Zaragoza: 1129-1140.

JAMES, S. (1999): The Atlantic Celts, Londres.

JIMÉNEZ FLORES, A.M. (2002): Pueblos y tumbas. El impacto oriental en los rituales funerarios del Extremo Occidente (2 vols.), Écija (Sevilla).

JONES, S. (1997): The Archaeology of Ethnicity. Constructing Identities in the Past and the Present, Londres.

----(1998): "Ethnic Identity as Discursive Strategy", CAJ 8 (2): 275-277.

KOCH, M. (2001): "Cartago e Hispania anteriores a los Bárquidas", en Religión, lengua y culturas prerromanas de Hispania. Actas del VIII Coloquio Internacional sobre Lenguas y Culturas Prerromanas de la Península Ibérica, Salamanca: 189-197.

KURTZ, W.S. (1995): "Lo céltico en el contexto de la arqueología europea", en A. Velázquez y J.J. Enríquez (eds.), Celtas y túrdulos: la Beturia (Cuadernos Emeritenses 6), Mérida: 9-48.

LACALLE RODRÍGUEZ, R. (1996): "Ensayo de definición arqueológica de las etnias prerromanas de Andalucía", Spal 5: 165-186.

LANCEL, S. (1994): Cartago, Barcelona.

LE ROUX, P. (1995): Romains d'Espagne: cités et politique dans les provinces (IIe siècle av. J.-C.IIIe siècle ap. J.-C.), París.

LÓPEZ CASTRO, J.L. (1991a): “Cartago y la Península Ibérica: ¿imperialismo o hegemonía?, en La caída de Tiro y el auge de Cartago (V Jornadas de Arqueología Fenicio-Púnica), Ibiza: 73-86.

-----(1991b): "El imperialismo cartaginés y las ciudades fenicias de la Península Ibérica entre los siglos VI y III a.C.", Studi di Egittologia e di Antichità Puniche 11: 87-107

-----(1992): “Fenicios y cartagineses en el Extremo Occidente: algunas cuestiones terminológicas y de periodización”, en Homenaje a la profesora Elena Pezzi, Granada: 343-348.

-----(1995): Hispania phoena. Los fenicios en la Hispania romana, Barcelona.

-----(2003): "La formación de las ciudades fenicias occidentales", Byrsa 2: 69-120.

-----(2004): "La identidad étnica de los fenicios occidentales", en G. Cruz Andreotti y B. Mora Serrano (coords.), Identidades étnicas Identidades políticas en el mundo prerromano hispano, Málaga: 147-167.

LÓPEZ ROA, C. (1978): "Las cerámicas alisadas con decoración bruñida", Huelva Arqueológica IV: 145-180.

MADOZ, P. (1949): Diccionario EstadísticoGeographico-Histórico de España y sus posesiones de Ultramar, XII, Madrid.

MALUQUER DE MOTES, J. (1970): Tartessos, Barcelona.

MANCEBO DÁVALOS, J. (1994): “Consideraciones sobre la cerámica gris a torno de Montemolín (Sevilla)", Zephyrus XLVII: 105-111.

MANCEBO, J. y otros (1992): "Las cerámicas grises a torno del yacimiento orientalizante de Montemolín (Sevilla)", TP 49: 277-293.

MARCO SIMÓN, F. (1986): "El dios céltico Lug y el santuario de Peñalba de Villastar", en Estudios en Homenaje al Dr. Antonio Beltrán Martínez, Zaragoza: 731-759.

MORET, P. (2004): “Ethnos ou ethnie? Avatars anciens et modernes des noms de peoples ibères", en G. Cruz Andreotti y B. Mora Serrano (coords.), Identidades étnicas - Identidades políticas en el mundo prerromano hispano, Málaga: 31-62.

MURILLO REDONDO, J.F. (1994): La cultura tartésica en el Guadalquivir Medio (Ariadna 13-14), Palma del Río (Córdoba).

NIVEAU DE VILLEDARY Y MARIÑAS, A.M ${ }^{\mathrm{a}}$. (2000): "La producción de cerámicas rojas de tradición griega en la zona de Cádiz”, MM 41: 178-196.

-----(2001): “El espacio geopolítico gaditano en época púnica. Revisión y puesta al día del concepto de «Círculo del Estrecho»", Gerión 19: 313-354.

-----(2004): “La cerámica púnico-gaditana del s. III a.C. El uso de la vajilla en el ámbito funerario y ritual de la necrópolis", en A. González, G. Matilla y A. Egea (eds.), El mundo púnico: religión, antropología y cultura material (Estudios Orientales 5-6), Murcia: 267-297. 
NIVEAU DE VILLEDARY, A.M ${ }^{\mathrm{a}}$. y RUIZ MATA, D. (2000): "El poblado de Las Cumbres (Castillo de Doña Blanca): urbanismo y materiales del s. III a.C.", en Actas del IV Congreso Internacional de Estudios Fenicio-Púnicos, Cádiz: 893-903.

ORDÓÑEZ AGULLA, S. (1996): “La romanización en Marchena", en Actas de las I Jornadas sobre Historia de Marchena, I, Sevilla: 37-63.

PELLICER CATALÁN, M. (1976-1978): "Problemática general de los inicios de la iberización en Andalucía Occidental", en Simposi Internacional: Els Orígens del Món Ibèric (Ampurias 38-40), Barcelona: 3-22.

PELLICER, M. y otros (1983): El Cerro Macareno (EAE 124), Madrid.

PEREIRA SIESO, J. (1988): “La cerámica ibérica de la cuenca del Guadalquivir, I. Propuesta de clasificación", TP 45: 143-173.

----(1989): “La cerámica ibérica de la cuenca del Guadalquivir, II. Conclusiones”, TP 46: 149-159.

PERICOT, L. (1950): La España primitiva, Barcelona.

PLÁCIDO, D. y otros (1991): La formación de los estados en el Mediterráneo Occidental, Madrid.

PLIEGO VÁZQUEZ, R. (2003): "Sobre el reclutamiento de mercenarios turdetanos: el campamento cartaginés de El Gandul (Alcalá de Guadaira, Sevilla)", Habis 34: 39-56.

PRONTERA, F. (1999): "Identità etnica, confini e frontiere nel mondo greco", en Atti del $37^{\circ}$ Convegno di Studi sulla Magna Grecia, Taranto: 147-166 = "Identidad étnica, confines y fronteras en el mundo griego", en Otra forma de mirar el espacio: Geografía e Historia en la Grecia antigua, Málaga, 2003.

RENFREW, C. (1998): "From here to ethnicity", CAJ 8 (2): $275-277$.

RODRIGO, V. y HABA, S. (1992): “Aguas medicinales y culto a las aguas en Extremadura", en Termalismo Antiguo. Aguas minero-medicinales, termas curativas y culto a las aguas en la Península Ibérica (ETF II-5), Madrid: 351-382.

ROOS, A. (1982): “Acerca de la antigua cerámica gris a torno de la Península Ibérica”, Ampurias 44: 4370 .

ROSSI, I. y O'HIGGINS, E. (1981): Teorías de la cultura y métodos antropológicos, Barcelona.

RUIZ MATA, D. (1987): "La formación de la cultura turdetana en la Bahía de Cádiz a través del Castillo de Doña Blanca", en Iberos. Actas de las
I Jornadas sobre Mundo Ibérico, Jaén: 299-314.

-----(1995): “Las cerámicas del Bronce Final. Un soporte tipológico para delimitar el tiempo y el espacio tartésico", en Tartesos 25 años después, 1968-1993, Jerez de la Frontera: 265-314.

----(1997): "Fenicios, tartesios y turdetanos", en La Andalucía Ibero-Turdetana (siglos VI-IV a.C.), (Huelva Arqueológica XIV), Huelva: 325-367.

-----(1998): "Turdetanos: origen, territorio y delimitación del tiempo histórico", REIb III: 153-221.

RUIZ MATA, D. y FERNÁNDEZ JURADO, J. (1986): El yacimiento metalúrgico de época tartésica de San Bartolomé de Almonte (Huelva), (Huelva Arqueológica VIII), Huelva.

RUIZ, A. y MOLINOS, M. (1993): Los Iberos. Análisis arqueológico de un proceso histórico, Barcelona.

RUIZ ZAPATERO, G. (1996): “Celts and Iberians. Ideological Manipulations in Spanish Archaeology", en P. Graves-Brown, S. Jones y C. Gamble (eds.), Cultural Identity and Archaeology: the Construction of European Communities, Londres: 179-195.

RUIZ ZAPATERO, G. y ÁLVAREZ-SANCHÍS, J.R. (2002): "Etnicidad y Arqueología: tras la identidad de los vetones", en Homenaje al Profesor Pellicer, II (Spal 11), Sevilla: 253-275.

RUIZ-GÁlVEZ PRIEGO, M. (1987): “Bronce Atlántico y 'cultura' del Bronce Atlántico en la Península Ibérica”, TP 44: 252-264.

SÁEZ FERNÁNDEZ, P. (1978): "Las centurias de la Bética", Habis 9: 255-271.

-----(1994): “Notas sobre pervivencias del elemento indígena en la Bética romana: cuestiones a debate", en C. González Román (ed.), La sociedad de la Bética. Contribuciones para su estudio, Granada: 461-493.

SAQUETE CHAMIZO, J.C. (1998): “L. Antonio L. F. Quir. Vegeto Turdulo y Estrabón 3.1.6. sobre la romanización de la Beturia Turdula", Habis 29: 117-129.

SECO SERRA, I. (1999): "El betilo estiliforme de Torreparedones", Spal 8: 135-158.

SHENNAN, S. (1989): "Introduction: Archaeological Approaches to Cultural Identity", en S. Shennan (ed.), Archaeological Approaches to Cultural Identity, Londres: 1-32.

SILGO GAUCHE, L. (1992): "Los límites étnicos de la Turdetania”, en Estudios de arqueología ibéri- 
ca y romana: Homenaje a E. Pla Ballester, Valencia: 365-372.

SOLÁ-SOLÉ, J.Ma . (1980): El alfabeto monetario de las cecas "libiofenices", Barcelona.

SOLANA, J.M. (ed.) (1991): Las entidades étnicas de la Meseta norte de Hispania en época prerromana. (Anejos de Hispania Antiqua), Valladolid.

SOUTHALL, A.W. (1970): "The Illusion of Tribe", en Peter C.W. Gutkind (ed.), The Passing of Tribal Man in Africa, Leiden: 28-50.

STRASBURGER, H. (1965): "Poseidonios on problems of the Roman Empire", JRS LV: 40-53.

TARRADELL, M. (1960): Marruecos púnico, Tetuán.

UNTERMAN, J. (1995): "La latinización de Hispania a través del documento monetal”, en $\mathrm{M}^{\mathrm{a}}$.P. García-Bellido y R.M. Sobral Centeno (eds.), $L a$ moneda hispánica: Ciudad y territorio (Anejos de AEspA XIV), Madrid: 305-316.
VALLEJO SÁNCHEZ, I. (1997): “Las cerámicas grises orientalizantes con decoración bruñida y las decoraciones indígenas", en XXIV CNA, Cartagena: 85-93.

----(1998): “Sobre el origen y extensión de la cerámica gris y las producciones occidentales", en Actas del Congreso "El Mediterráneo en la Antigüedad: Oriente y Occidente”, Sapanu, Publicaciones en Internet, II (1998) [http://www.labherm.filol.csic.es].

----(1999): “Las decoraciones bruñidas en las cerámicas grises orientalizantes", Spal 8: 85-100.

VILLARONGA Y GARRIGA, L. (1979-1980): "Las monedas de Urso", Ampurias 41-42: 243-256.

ZAMORA ACOSTA, E. (1988): “Grupo étnico", en A. Aguirre Baztán (ed.), Diccionario temático de Antropología, Madrid. 